\title{
Carbonatitic lavas in Catanda (Kwanza Sul, Angola): mineralogical, geochemical and melt inclusion constraints on the natrocarbonatite parental melt
}

Marc Campeny, Dept. Cristal·lografia, Mineralogia i Dipòsits Minerals, Universitat de Barcelona, Barcelona, Catalonia, Spain. mcampeny@ub.edu

Vadim S. Kamenetsky, School of Physical Sciences, University of Tasmania, Hobart, Australia

Joan C. Melgarejo, Dept. Cristal·lografia, Mineralogia i Dipòsits Minerals, Universitat de Barcelona, Barcelona, Catalonia, Spain.

José Mangas, Depto. Física, Instituto de Oceanografía y Cambio Global, Universidad de Las Palmas de Gran Canaria, Spain.

José Manuel, Depto. Geologia, Universidade Agostinho Neto, Luanda, Angola.

Pura Alfonso, Dept. Enginyeria Minera i Recursos Naturals, Universitat Politècnica de Catalunya,

Manresa, Catalonia, Spain

Maya Kamenetsky, School of Physical Sciences, University of Tasmania, Hobart, Australia

Aurora C.J.M. Bambi, Depto. Geologia, Universidade Agostinho Neto, Luanda, Angola.

Antonio O. Gonçalves, Depto. Geologia, Universidade Agostinho Neto, Luanda, Angola.

\section{Abstract}

A set of small volcanic edifices with tuff ring and maar morphologies occur in the Catanda area, which is the only locality with extrusive carbonatites reported in Angola. Four outcrops of carbonatite lavas have been identified in this region and considering the mineralogical, textural and compositional features, we classify them as: silicocarbonatites (1), calciocarbonatites (2) and secondary calciocarbonatites produced by the alteration of primary natrocarbonatites (1). Even with their differences, we interpret these lava types as having been a single carbonatite suite related to the same parental magma. We have also estimated the composition of the parental magma from a study of melt inclusions hosted in magnetite microphenocrysts from all of these lavas. Melt inclusions revealed the presence of 13 different alkali-rich phases, including nyerereite, shortite, halite and sylvite arguing for an alkaline composition of the Catanda parental melts. Mineralogical, textural, compositional and isotopic features of some Catanda lavas are also similar to those described in altered natrocarbonatite localities worldwide such as Tinderet or Kerimasi, leading to our conclusion that the formation of some Catanda calciocarbonatite lavas was related to the occurrence of natrocarbonatite magmatism in this area. On the other hand, silicocarbonatite lavas, which are enriched in periclase, present very different mineralogical, compositional and isotopic features in comparison to the rest of Catanda lavas. We conclude that its formation was related with the decarbonation of primary dolomite bearing carbonatites.

Key words: extrusive carbonatites, carbonatitic lavas, melt inclusions, calciocarbonatites, silicocarbonatites, natrocarbonatites, Angola, Catanda 


\section{Introduction}

There are approximately 527 known carbonatite localities worldwide (Woolley and Kjarsgaard, 2008). Most of these carbonatites (480) are formed in plutonic or hypabyssal environments, while only a minority (47) are extrusive and associated with volcanic eruptions (Woolley and Church, 2005). These volcanic carbonatites are mainly formed by pyroclastic materials from explosive volcanism (33), while effusive carbonatite lavas have only been described in 14 localities (Woolley and Church, 2005).

Carbonatite magmas most probably represent low-degree partial melts of the lithospheric mantle (Wallace and Green, 1988; Bell and Simonetti, 2010). Therefore, the study of such extrusive products, especially lavas, provides significant information about their genesis and the distribution and partitioning of chemical elements such as Rare Earth Elements (REE) (Hornig-Kjarsgaard, 1998; Chakhmouradian and Wall, 2012) and High Field Strength Elements (HFSE) (Chakhmouradian, 2006; Dalou et al., 2009).

Even so, due to their rarity, the scientific literature about carbonatite lavas is very limited. Complete geochemical and petrogenetic studies have only been reported for a few localities, primarily located in the East African Rift (Woolley, 2001) such as Fort Portal, Uganda (von Knorring and Du Bois, 1961; Nixon and Hornung, 1973; Barker and Nixon, 1989; Eby et al., 2009), Kerimasi (Church, 1996) and Oldoinyo Lengai in Tanzania (Dawson, 1962a; Dawson et al., 1995a; Keller and Zaitsev, 2012). Oldoinyo Lengai is the only active carbonatite volcano known, and where unique natrocarbonatite lavas have also been carefully studied (Dawson, 1962b; Dawson et al., 1995b, Bell and Keller, 1995; Mitchell and Kamenetsky, 2012). However, the published data about carbonatite lavas outside the Eastern African Rift are scarce, and a significant information gap exists in relation to this topic.

In the present contribution, we report mineralogical, geochemical, stable isotopes and melt inclusion data on the carbonatite lavas from Catanda, Angola. This carbonatite locality was first reported by Silva and Pereira (1973), but the Angolan civil war hampered the access to the area and prevented more detailed studies, until Campeny et al. (2014) described the volcanic processes related to the carbonatites emplacement. These relatively fresh carbonatite lavas located in the western African margin, are in a tectonic region affected by the break-up of Gondwana (Issa Filho et al., 1991), where carbonatite magmatism is also associated to kimberlite pipes (RoblesCruz et al., 2012).

The aim of this work is to investigate these well-preserved carbonatite lavas through a detailed petrographic description and comparing their textural and mineralogical features with other carbonatite and natrocarbonatite localities worldwide. Melt inclusion study have also permitted constraints on the composition of Catanda parental melt, which has been determined as alkali-rich. 


\section{Geological setting}

The Catanda carbonatites are located in the Kwanza Sul province (Angola), approximately $50 \mathrm{~km} \mathrm{SE}$ of the town of Sumbe and $250 \mathrm{~km}$ south of Luanda, the national capital. They were produced by a group of relatively eroded monogenetic volcanic cones outcropping in a $50 \mathrm{~km}^{2}$ graben hosted in Archaean granites (Fig. 1). The volcanic edifices of Catanda have principally tuff ring and maar morphologies, which contain a series of volcanic units up to $100 \mathrm{~m}$ thick (Campeny et al., 2014). The eruptive activity in the area was predominantly explosive, since most of the volcanic series are pyroclastics. However, effusive activity is also reported, and four outcrops of carbonatite lavas - Huilala-Ungongué, Ipunda, Jango and Utihohala have been described (Fig. 1).

The Catanda carbonatites are structurally associated with the Lucapa corridor, an extensional belt oriented NE-SW across the Congo-Kassai craton, related to the breakup of Gondwana during the Cretaceous (Issa Filho et al., 1991). Most of the Angolan carbonatites are distributed along this rift including Virulundo, Tchivira-Bonga, Bailundoor Longonjo (Torró et al., 2011; Melgarejo et al., 2012; Calvo et al., 2011a; Calvo et al., 2011b), along with kimberlites including the Catoca pipe (Robles-Cruz et al., 2012; Korolev et al., 2014), which is one of the most productive diamond mines in the African continent.

The volcanic activity in the Catanda region has never been precisely dated. Silva and Pereira (1973) proposed a $92 \mathrm{Ma}( \pm 7) \mathrm{K}-\mathrm{Ar}$ age (Torquato and Amaral, 1973) for a tinguaite dyke assumed to be contemporary with the carbonatite outcrops. This age is younger than the formation of the Lucapa corridor and the Catoca kimberlite, dated as Early Cretaceous (Robles-Cruz et al., 2012). However, the occurrence of multiple episodes of magmatic activity, including those during the Cretaceous, cannot be ruled out and future accurate dating is highly desirable in the area.

\section{Analytical methods}

Textural and mineralogical studies were carried out by optical microscopy as well as with an E-SEM-Quanta 200 FEI-XTE-325/D8395.BSE Scanning Electron Microscope with a Genesis EDS microanalysis system, at the Scientific and Technical Centre of the University of Barcelona (CCiTUB). Operating conditions were $25 \mathrm{kV}, 1 \mathrm{nA}$ beam current and $15 \mathrm{~mm}$ distance to detector.

Whole rock major and trace element analyses were performed by conventional X-ray fluorescence (XRF) and ICP-emission spectrometry following a lithium metaborate/tetraborate fusion and nitric acid digestion at the ACME Analytical Laboratories Ltd. from Vancouver, Canada. 
Calcite, magnetite, fluorapatite, and phlogopite compositions were analysed with wavelength-dispersive spectrometry (EPMA-WDS) at CCiTUB, using a Cameca SX50 electron microprobe. Results were processed using the PAP matrix correction programme (Pichou and Pichoir, 1984). Operating conditions were an accelerating voltage of $15-20 \mathrm{kV}$ combined with a beam current of 5 to $20 \mathrm{nA}$ and a 10-15 $\mu \mathrm{m}$ of spot beam diameter. Standards used for the analyses were: fluorite $(F, K \alpha)$; albite $(\mathrm{Na}$, $\mathrm{K} \alpha)$; periclase $(\mathrm{Mg}, \mathrm{K} \alpha) ; \mathrm{Al}_{2} \mathrm{O}_{3}(\mathrm{Al}, \mathrm{K} \alpha)$; diopside $(\mathrm{Si}, \mathrm{K} \alpha)$; fluorapatite $(\mathrm{P}, \mathrm{K} \alpha) ; \mathrm{AgCl}_{2}(\mathrm{Cl}$, $\mathrm{K} \alpha)$; orthoclase $(\mathrm{K}, \mathrm{K} \alpha)$; wollastonite $(\mathrm{Ca}, \mathrm{K} \alpha)$; rutile $(\mathrm{Ti}, \mathrm{K} \alpha)$; metallic vanadium $(\mathrm{V}, \mathrm{K} \alpha)$; $\mathrm{Cr}_{2} \mathrm{O}_{3}(\mathrm{Cr}, \mathrm{K} \alpha)$; rhodonite $(\mathrm{Mn}, \mathrm{K} \alpha) ; \mathrm{Fe}_{2} \mathrm{O}_{3}(\mathrm{Fe}, \mathrm{K} \alpha)$; sphalerite $(\mathrm{Zn}, \mathrm{K} \alpha)$; celestine $(\mathrm{Sr}, \mathrm{L} \alpha)$; $\mathrm{LaB}_{6}(\mathrm{La}, \mathrm{L} \alpha)$ and $\mathrm{CeO}_{2}(\mathrm{Ce}, \mathrm{L} \alpha)$.

Trace element compositions of calcite were also obtained using a Coherent COMPex Pro-ArF Excimer LA-ICP-MS equipment at the LA-ICP-MS Laboratory in the School of Earth Sciences of the University of Tasmania (Australia).

Stable isotope analyses of $C$ and $O$ were carried out in the Isotope-ratio mass spectrometry (IRMS) laboratory of the CCiTUB. The $\mathrm{CO}_{2}$ extraction used the method of McCrea (1950) with a 3 minute carbonate digestion with phosphoric acid at $70^{\circ} \mathrm{C}$. Measurements were carried out with a MAT-252 Thermo Finnigan isotopic mass relations spectrometer. The international reference samples used were NBS-18 $\left(\delta^{13} \mathrm{C}\right.$ $(P D B)=-5.1 \% ; \delta^{18} O(P D B)=-23.2 \%$ o $)$ and NBS-19 $\left(\delta^{13} C(P D B)=+1.95 \% ; \delta^{18} O(P D B)=-\right.$ $2.20 \%$ ). The standard deviation of measurements was 0.06 for $\delta^{13} \mathrm{C}$ and 0.05 for $\delta^{18} \mathrm{O}$.

Melt inclusion studies were performed using petrographic microscopy, scanning electron microscopy using a FEI Quanta 600 MLA ESEM coupled with energy dispersive X-ray spectroscopy analysis, and a Hitachi SU-70 Field Emission Scanning Electron Microscopy (FESEM) at the Central Science Laboratory of the University of Tasmania (Australia).

\section{Petrography of lavas}

Four outcrops of carbonatite lavas are identified in the Catanda area (Campeny et al., 2014), namely Huilala-Ungongué, Ipunda, Jango and Utihohala, distinct in their mineralogical and textural characteristics (Table 1).

\subsection{Huilala-Ungongué}

These carbonatite lavas are located in the Huilala and the Ungongue hills (Fig. 1) in outcrops formed by an alternating series of lavas and lapilli tuffs (Campeny et al., 2014). Huilala-Ungongué lavas are fine-grained porphyritic dark grey rocks with a very low modal percentage of carbonates ( $\approx 30$ modal \%). Microphenocrysts comprise up to 
$\approx 20$ modal $\%$, and they are mainly fluorapatite (35 modal \%), magnetite (35 modal \%), titaniferous augite (15 modal \%) and phlogopite (15 modal \%). Fluorapatite microphenocrysts form subhedral grains consisting of hexagonal prisms and pinacoids with a short prismatic habit up to $1 \mathrm{~mm}$ across, which are occasionally strongly zoned. Magnetite is present as euhedral crystals up to $0.5-1 \mathrm{~mm}$ in diameter (Fig. 2a), occasionally fractured and presenting corroded borders. They also exhibit a marked concentric zoning, forming typical atoll textures and contain inclusions of minerals such as perovskite, pyrite and pyrrhotite. Titaniferous augite is present as subhedral rounded microphenocrysts of 1 to $2 \mathrm{~mm}$ that may replace magnetite (Fig. 2a); some augite crystals show a marked compositional zoning. Phlogopite grains form zoned angular crystals up to $3 \mathrm{~mm}$ across.

The rock is up to 80 modal \% groundmass, which has a very complex mineral assemblage (Fig. 2b). Fine grained calcite is dominant and is accompanied by accessory minerals such as fluorapatite, magnetite, cuspidine, perovskite, pyrochlore, baddeleyite, periclase, brucite and scarce grains of zirconolite, spurrite and very rare oldhamite. Groundmass fluorapatite is present as zoned euhedral crystals up to 100 $\mu \mathrm{m}$ in length, while magnetite generally forms zoned euhedral grains up to $200 \mu \mathrm{m}$. Cuspidine, which is commonly intergrown with fluorapatite grains, forms short euhedral to subhedral prismatic crystals up to $50 \mu \mathrm{m}$ (Fig. 2c). Perovskite is present as euhedral to subhedral grains up to $40 \mu \mathrm{m}$ in size, with very marked compositional zoning (Fig. 2d). Pyrochlore is another common mineral in the groundmass. It is typically included in calcite, but it may also occur as inclusions in other minerals such as magnetite or brucite (Fig. 2e). Pyrochlore occurs as small euhedral grains, less than $20 \mu \mathrm{m}$ in diameter, often slightly corroded. It is generally well zoned and up to three generations of pyrochlore may be distinguished in some grains (Bambi et al., 2012; Melgarejo et al., 2012). Brucite is widely present in the Huilala-Ungongué samples, typically as pseudomorphs after primary grains of periclase. This replacement is typically completed, but subhedral periclase crystals of 5 to $10 \mu \mathrm{m}$ may still be preserved as cores with altered rims of brucite (Fig. 2f). Periclase grains contain inclusions of magnetite, perovskite, fine-grained pyrochlore and baddeleyite, occurring as 5 to $10 \mu \mathrm{m}$ anhedral grains. These minerals are also commonly included in other minerals such as perovskite and magnetite. Spurrite is a very scarce phase sometimes associated to cuspidine as anhedral grains of less than 5-10 $\mu \mathrm{m}$. Rare zirconolite and oldhamite crystals of less than $10 \mu \mathrm{m}$ in diameter are occasionally found as inclusions in other minerals.

Subhedral grains of barite up to $0.5 \mathrm{~mm}$ are also common as well as occasionally secondary fibrous thaumasite and phosphates such as rhabdophane or crandallite.

\subsection{Ipunda}


Ipunda lavas are cream-colored fine-grained porphyritic rocks, with $\approx 70$ modal $\%$ calcite. They are characterised by a very distinctive trachytoid texture made up of tabular calcite microphenocrysts dominating an interstitial sparry carbonate matrix (Fig. 3a). The microphenocrysts are colourless tabular grains (60 modal \%) up to $1 \mathrm{~mm}$ in length, accompanied by strongly zoned magnetite (15 modal \%) up to $1 \mathrm{~mm}$ and euhedral grains of fluorapatite (15 modal \%) up to $2 \mathrm{~mm}$ in length, with concentric zoning and abundant fluid inclusions trapped at the crystal cores. Phlogopite ( 5 modal $\%$ ) crystals up to $1 \mathrm{~mm}$ and very scarce grains of zoned augite (5 modal \%) are also present as microphenocrysts.

The mineralogy of the groundmass is very simple compared to the Huilala-Ungongue lavas. Fine-grained calcite is the dominant phase (75 modal \%); fluorapatite (10 modal \%) (Fig. $3 \mathrm{~b}$ and $3 \mathrm{c}$ ) and magnetite ( 5 modal \%) are also present. The rest of accessory minerals account for only approximately 5 modal \% and are euhedral zoned grains of pyrochlore, less than $20 \mu \mathrm{m}$ in diameter and scarce anhedral baddeleyite grains of less than $10 \mu \mathrm{m}$, mostly included in magnetite crystals.

Spherical globules up to $1 \mathrm{~mm}$ in diameter are abundant in the matrix and are completely infilled by secondary sparry calcite with minor goethite inclusions (Fig. $3 \mathrm{~b}$ and $3 c)$.

\subsection{Utihohala}

Utihohala rocks are fine-grained porphyritic (Fig. 4a) dark brown lavas containing $\approx 60$ modal \% carbonates. Microphenocrysts represent around 25 modal \% and are prismatic grains of apatite up to $2 \mathrm{~mm}$ (50 modal \%), as well as strongly zoned magnetite grains up to $2 \mathrm{~mm}$ in size (30 modal \%). Prismatic euhedral phlogopite (15 modal \%) up to $1 \mathrm{~mm}$ across and zoned augite ( 5 modal \%) grains up to $0.5 \mathrm{~mm}$ are also present (Fig. 4a).

The groundmass occupies 75 modal \% and it is mainly calcite (60 modal \%), fluorapatite (10 modal \%) (Fig. 4b), magnetite (10 modal \%) and a small proportion of accessory minerals ( $\approx 10$ modal $\%$ ) such as euhedral grains of pyrochlore up to $20 \mu \mathrm{m}$, scarce grains of baddeleyite up to $15 \mu \mathrm{m}$ and euhedral crystals of alabandite up to 5 $\mu \mathrm{m}$, which, in Catanda, were only found in these lavas.

\subsection{Jango}

The mineralogy and textures of the Jango lavas are very similar to those in the Utihohala area. The Jango lavas are brown fine-grained porphyritic textured rocks (Fig. 4 c) with $\approx 70$ modal \% carbonates, significantly higher than the Huilala-Ungongué lavas. 
Microphenocrysts are sparse $(\approx 20$ modal $\%)$ in an abundant groundmass. They are principally euhedral grains of fluorapatite up to $1 \mathrm{~mm}$ in diameter (60 modal \%), euhedral zoned crystals of magnetite up to $2 \mathrm{~mm}$ ( 25 modal \%) in which is also possible to distinguish atoll textures, as well as euhedral grains of phlogopite (10 modal \%) up to $2 \mathrm{~mm}$ and scarce zoned augite ( 5 modal \%) up to $0.5 \mathrm{~mm}$.

The groundmass, ( $\approx 80$ modal $\%)$ is mainly fine-grained calcite (65 modal \%), fluorapatite (15 modal \%), magnetite (10 modal \%) and accessory minerals (10 modal $\%)$ such as zoned euhedral crystals of pyrochlore up to $10 \mu \mathrm{m}$, subhedral prismatic monticellite crystals up to $30 \mu \mathrm{m}$, and scarce subhedral grains of baddeleyite up to 15 $\mu \mathrm{m}$ mostly as inclusion in magnetite.

Fractures filled by sparry calcite are common (Fig. 4c) as well as vesicles up to $3 \mathrm{~mm}$ partially filled by sparry carbonates (Fig. 4d).

\subsection{Xenoliths}

In all lava types xenocrystic material is less than about 5 modal \%. The most common xenoliths in the Catanda lavas are, by far, highly fenitized granitic rocks derived from the underlying Archaean granites. They form fragments up to $4 \mathrm{~cm}$; individual grains of quartz, microcline and plagioclase are also common as xenocrysts. Rounded xenoliths of glimmerite and amphibolite are occasionally present in the Catanda lavas. In the Huilala-Ungongué lavas there are occasional rounded grains of olivine (Peres et al., 1968) up to $5 \mathrm{~mm}$ in diameter, usually replaced by serpentine and fine-grained iron oxides.

\section{Mineral chemistry}

The four major microphenocryst mineral phases in all Catanda lavas: calcite, spinel, fluorapatite and phlogopite, were selected to study their chemical composition.

\subsection{Calcite}

Calcite is the dominant magmatic carbonate in all the Catanda lavas; other carbonates such as dolomite, ankerite or siderite are not present either as microphenocrysts or in the groundmass. Calcite major elements composition is homogeneous in all carbonatite lavas, but trace elements present significant differences (Table 2). These trace element differences are also reflected in the response of Catanda carbonates to cold cathodoluminescence, since cathodoluminescence is related to factors including the presence of some trace elements acting as activators such as $\mathrm{Mn}^{2+}$ and REEs (Habermann et al., 1996). In general, Catanda calcite emits a strong orange glow, but 
this glow is completely absent in the typical sparry grains present in all lava types. It is also remarkable that, under cold cathodoluminiscence, tabular calcite microphenocrysts of the Ipunda lavas, which form a typical trachytoidal texture, exhibit a marked concentric zoning (Fig. $5 a$ and $5 b$ ).

\subsection{Spinel}

Spinel group minerals from Catanda have very heterogeneous compositions due to extreme zoning present in most grains. However, in general, they correspond to magnetite with high $\mathrm{Ti}$ concentration, up to $14.4 \mathrm{wt} . \% \mathrm{TiO}_{2}(0.130$ to 0.408 apfu of $\mathrm{Ti}$, Table 3). Aluminium contents are also high, up to $14.3 \mathrm{wt} . \% \mathrm{Al}_{2} \mathrm{O}_{3}$, similar to those described in the Fort Portal volcanic carbonatites, which are the highest reported Al contents in magnetite from carbonatites (Bailey and Kearns, 2002; Reguir et al., 2008). The spinel from Catanda are also moderately enriched in $\mathrm{Mg}$, with contents ranging from 4.9 to $12.0 \mathrm{wt} . \% \mathrm{MgO}$, similar to those described in other volcanic carbonatite localities such as Kerimasi (Tanzania) or Fort Portal (Uganda) (Bailey and Kearns 2002). The relation between \#Ti $[\mathrm{Ti} /(\mathrm{Ti}+\mathrm{Cr}+\mathrm{Al})]$ and $\# \mathrm{Fe}[\mathrm{Fe} /(\mathrm{Fe}+\mathrm{Mg})]$ shows a clear titanomagnetite trend (Fig. 6) such as typically described in some kimberlites (Boctor and Boyd, 1982; Rozova et al., 1982) and aillikite localities (Tappe et al., 2006). Another significant compositional feature of the analysed spinels is the low content of $\mathrm{Cr}$, which is always below $0.1 \mathrm{wt} . \% \mathrm{Cr}_{2} \mathrm{O}_{3}$ (Table 3 ).

\subsection{Fluorapatite}

Fluorapatite is present as microphenocrysts as well as in the groundmass in all of the Catanda lavas, and its composition does not present significant differences among the different lava locations. In general, fluorapatite has low concentrations of $\mathrm{Mn}$ and $\mathrm{Na}$, while it is slightly enriched in Sr, ranging from 0.3 to 1.4 wt.\% (Table 4). Catanda fluorapatite is especially rich in Light Rare Earth Elements (LREE) with La contents between 670 and 990 ppm and Ce ranging from 1700 to 2460 ppm (Table 4). This enrichment is generally marked by a strong compositional zoning due to the concentration of REE in the grain rims, which are also enriched in $\mathrm{SiO}_{2}$.

\subsection{Phlogopite}

Phlogopite occurs as microphenocrysts in all the Catanda lavas and has similar compositions in all of them. In general, Catanda phlogopite is enriched in $\mathrm{TiO}_{2}$, ranging from 1.17 to $4.2 \mathrm{wt}$ \% (Table 5) and also has significant contents of $\mathrm{Ba}$, especially in the Huilala-Ungongué samples with contents up to 0.39 wt.\% $\mathrm{BaO}$ (Table 5). 


\section{Geochemistry of lavas}

The outcropping lavas of the Huilala-Ungongué area (Fig. 1) are the most enriched in $\mathrm{SiO}_{2}$, with contents varying between 14.3 and $23.3 \mathrm{wt} . \%$ (Table 6). Similar silica contents in carbonatites have been reported in the lavas from Fort Portal (Uganda) (Eby et al., 2009), as well as in other carbonate-rich rocks such as the aillikites from Aillik Bay in (Canada) and Tikiusaaq (Greenland) (Tappe et al., 2006; Tappe et al., 2009). However, the lavas from Ipunda, Jango and Utihohala (Fig. 1) have lower $\mathrm{SiO}_{2}$ concentrations, ranging from 6.3 to $12.7 \mathrm{wt} . \%$. In general, the Huilala-Ungongué lavas are also enriched in $\mathrm{Ti}, \mathrm{Al}$ and Fe compared to the other localities, which are also distinguished by a relative enrichment in $\mathrm{CaO}$, with values up to $46.5 \mathrm{wt}$.\% (Table 6).

All the lava types from the Catanda area are impoverished in alkalis, with $\mathrm{K}$ and $\mathrm{Na}$ contents well below 1 wt.\%.

Fluorine is variable depending on the lava outcrop. The highest concentrations are found in the Huilala-Ungongué and Utihohala lavas with values from 4470 to 6790 and $6850 \mathrm{ppm}$ respectively, while in the rest fluorine is lower, varying from 4040 to 4330 ppm in Jango and only 1570 ppm in the Ipunda outcrops (Table 6).

In general, the Catanda carbonatite lavas are distinguished by REE contents between 1100 and 3000 ppm, higher than those described in other extrusive carbonatite localities such as Fort Portal (Eby et al., 2009). HFSE contents are generally high in all types of lavas. Niobium is the most abundant HFSE with values between 281 to 706 ppm, while Ta values reach $23 \mathrm{ppm}$, which are relatively high compared to average of other carbonatite localities (Chakhmouradian, 2006). The Nb/Ta ratio of Catanda lavas are between 21 and 37 which are typical values of carbonatites (Chakhmouradian, 2006).

REE diagrams of carbonatite lavas from Catanda do not show clear differences between the different lavas. All patterns present a marked negative slope showing a strong enrichment in light REE relative to heavy REE (Fig. 7a).

As in the REE diagrams, multi-elemental diagrams show very similar patterns between the four lava locations (Fig. 7b).

\section{Stable isotopes}

Table 7 presents the stable isotope composition $\left(\delta^{13} \mathrm{C}\right.$ and $\left.\delta^{18} \mathrm{O}\right)$ of the Catanda groundmass carbonates. As standards for comparison, we have added two samples of secondary sparry carbonate infilling cavities of the lavas, as well as a sample from the Pedra de Água travertine deposit (Fig. 1). 
The $\delta^{18} \mathrm{O}_{(\mathrm{V} \text {-sMow })}$ compositions are very heterogeneous, with values ranging from 9.4 to $17.9 \% \delta^{18} \mathrm{O}$ (Table 7). On the other hand, secondary sparry carbonate and the travertine samples show much heavier oxygen isotope composition compared to magmatic carbonates with $\delta^{18} \mathrm{O}_{(\mathrm{V} \text {-SMOW) }}$ values between 26.4 and $27.2 \%$ o $\delta^{18} \mathrm{O}$.

Compositions of $\delta^{13} \mathrm{C}$ are similar in the Ipunda, Jango and Utihohala magmatic carbonates with values ranging from -5.2 to $-5.6 \% \delta^{13} \mathrm{C}_{(\mathrm{V}-\mathrm{PDB})}$. On the other hand, Huilala-Ungongué lavas show marked differences to the other localities, presenting lighter $\delta^{13} \mathrm{C}$ compositions with values from -8.1 to $-12.2 \% \delta^{13} \mathrm{C}$. Secondary carbonate $\delta^{13} \mathrm{C}$ compositions are significantly heavier and more variable than in the lavas $\left(\delta^{13} \mathrm{C}\right.$ compositions between -4.2 and $-1.0 \%$ ), while the Pedra de Água travertine present $\delta^{13} \mathrm{C}$ of $6.4 \%$, which is the heaviest carbon isotope composition reported in the rocks from the Catanda area.

\section{Melt inclusions}

The mineralogical study of the Catanda lavas were complemented with the analysis of the melt inclusions assemblages preserved in magnetite grains. Approximately 200 melt inclusions, with sizes varying from 5 to $25 \mu \mathrm{m}$, were studied from all carbonatite lava localities reported in the Catanda area, and 24 daughter phases have been identified. These minerals, including calcite, fluorapatite, perovskite and cuspidine, are generally present in the lavas, although other phases are exclusive to the melt inclusions assemblage, and have been not described as microphenocrysts or in the lavas groundmass (Table 8). In addition, despite the generally low alkali contents of the Catanda lavas, up to 12 of the 24 daughter phases described in the melt inclusions are alkali-rich, e.g. carbonates such as trona (Fig. 8a) shortite (Fig. 8b and 8d) and nyerereite, halides such as halite and sylvite (Fig. $8 \mathrm{c}$ ) and silicates such as sodalite and nepheline (Fig. 8b).

\section{Discussion}

\subsection{Classification of the Catanda lavas}

In the Catanda area, two main types of carbonatitic lavas may be defined based on their carbonate contents and chemical composition: calciocarbonatites and silicocarbonatites.

Calciocarbonatites occur in the Ipunda, Jango and Utihohala areas. Their modal carbonate contents are higher than $50 \%$, corresponding to normal carbonatites according to the classification of Le Maitre (2002). However, strong textural differences may be established between these three localities. Jango and Utihohala 
lavas present finely porphyritic textures formed by fluorapatite, magnetite, phlogopite and minor augite microphenocrysts hosted in a calcite rich groundmass (Table 1), while Ipunda lava is characterised by a trachytoid texture formed by tabular microphenocrysts of calcite.

The Ipunda texture is similar to that described in other carbonatite localities such as the Koru Beds from Tinderet (Kenya), the carbonatites from Homa Mountain (Kenya), the spherical lapilli of the Rockeskyll complex (Germany) or the carbonatite tephras of the Kerimasi volcano (Tanzania) (Deans and Roberts, 1984; Clark and Roberts, 1986; Keller, 1981; Riley et al., 1996; Hay, 1983). In the Kerimasi tephra, calcite also shows concentric zoning under cold cathodoluminescence (Mariano and Roedder, 1983) as also described in the Ipunda lavas (Fig. 5). The origin of these trachytoid textures has been controversial over time, until Zaitsev et al., 2013 studied them in Tinderet and concluded that calcite tabular crystals were formed by alteration of primary alkaline carbonates. It is well known that alkaline carbonates such as nyerereite or gregoryite are very unstable, and easily altered to calcium carbonates during secondary weathering processes, as described in the Oldoinyo Lengai natrocarbonatite flows (Zaitsev and Keller, 2006). In our view, Ipunda trachytoid texture is also due to the alteration of primary alkaline carbonates; subsequently pseudomorphed to calcite in an analogous process as proposed for Tinderet (Zaitsev et al., 2013) and also probably occurred in other carbonatite localities with similar textures.

On the other hand, silicocarbonatites from the Catanda area are present in the HuilalaUngongué outcrops. These lavas are significantly enriched in $\mathrm{SiO}_{2}$ (Table 5) and present a finely porphyritic texture in which microphenocrysts are made up of fluorapatite, phlogopite, augite and magnetite, hosted in a calcite rich groundmass which also contain other accessory phases such as cuspidine, pyrochlore, perovskite and periclase. Similar $\mathrm{SiO}_{2}$ contents and mineralogy have been reported in other silica-rich carbonatite lavas such as in Fort Portal (Uganda) or in the aillikites from Aillik Bay (Canada) (Eby et al., 2009; Tappe et al. 2006).

Hence, the four carbonatitic lavas described in Catanda, which present several compositional, textural and mineralogical differences may be classified as: primary calciocarbonatites (Jango and Utihohala), secondary calciocarbonatites produced by the alteration of primary natrocarbonatite lavas (Ipunda) and silicocarbonatites (Huilala-Ungongué).

\subsection{Parental magma composition}

Trace element contents are similar for all lava locations and the REE and multielemental diagrams (Fig. 7) also present very similar patterns for all reported outcrops. These data suggest that despite their different appearance, the carbonatite lavas from Catanda form a unique carbonatite suite, where all lavas are genetically related and 
probably originated by pre or post emplacement differentiation from a same original parental magma.

The original composition of the Catanda parental magma has been extrapolated through the study of melt inclusions, which are hosted in the magnetite grains in all the Catanda lava outcrops. Despite the low alkalinity of the Catanda lavas (Table 6) and the low alkali content of their carbonates (Table 2), the daughter mineral assemblage of the magnetite-hosted melt inclusions from all lava locations is made up by primarily sodium- and potassium-rich mineral phases (Fig. 8; Table 8). Similar alkaline melt inclusion association has been described in the intrusive carbonatites from Oka (Canada), in kimberlite pipes such as Udachnaya-East (Russia) as well as in several carbonatite extrusive localities such as Kerimasi (Tanzania) or the Oldoinyo Lengai volcano (Tanzania) (Chen et al., 2013; Kamenetsky et al., 2007; Sharygin et al., 2008; Kamenetsky et al., 2014; Guzmics et al., 2011; Sharygin et al., 2012). Hence, Catanda is the first extrusive carbonatite outside the East African Rift where an assemblage of alkaline melt inclusions is described.

The occurrence of alkaline associations in melt inclusions, formed by phases such as trona, shortite or nyerereite (Table 8) suggest that the formation of Catanda carbonatite lavas implies the occurrence of natrocarbonatite composition parental magmas.

\subsection{Genetic processes}

Apart of the melt inclusion evidence and the trachytoid textures described in the Ipunda lavas, there are other indicators which support the relation between Catanda extrusive carbonatites and the occurrence of natrocarbonatitic magmatism in the area.

The composition of Catanda rock-forming carbonates has been compared with altered natrocarbonatites from Kerimasi and Tinderet, as well with the primary Oldoinyo Lengai natrocarbonatites (Fig. 9). Calcite from Ipunda, Jango and Utihohala, which generally have low $\mathrm{Na}$ contents (Table 2 ), have $\mathrm{SrO} / \mathrm{Na}_{2} \mathrm{O}$ ratios similar to those reported in the altered natrocarbonatite tephra from the Kerimasi volcano (Zaitsev et al. 2013) indicating that carbonate from these Catanda lavas have equivalent $\mathrm{Sr}$ and $\mathrm{Na}$ contents to those reported in altered natrocarbonatites localities.

The isotopic $\delta^{13} \mathrm{C}$ and $\delta^{18} \mathrm{O}$ signatures of the Catanda calciocarbonatites magmatic carbonates also present similarities to those reported in altered natrocarbonatites (Fig. 10). The calciocarbonatite lavas from Jango and Utihohala, as well as the altered natrocarbonatite lavas from the Ipunda area exhibit a $\delta^{13} \mathrm{C} / \delta^{18} \mathrm{O}$ ratio, which plots between the altered natrocarbonatites from Tinderet and Kerimasi and the primary natrocarbonatites from the Oldoinyo Lengai (Fig. 10). In addition, the secondary sparry 
calcite analysed in these Catanda localities present similar $\delta^{13} \mathrm{C} / \delta^{18} \mathrm{O}$ compositions to those reported in the secondary carbonates from Buru and Oldoinyo Lengai (Zaitsev and Keller, 2006) (Fig. 10). These isotopic relations indicate that calciocarbonatite lavas from Catanda are isotopically comparable to the altered natrocarbonatites worldwide, as well as their secondary sparry carbonates, which have also a similar $\delta^{13} \mathrm{C} / \delta^{18} \mathrm{O}$ ratio to those reported in the secondary carbonates analysed in these localities. The evolutionary trend of primary carbonates towards heavier oxygen isotopic compositions is typically related to fluid alteration processes (Fig. 10) including the alteration of primary alkaline carbonates to calcium rich phases.

On the other hand, silicocarbonatites from the Huilala-Ungongué area do not present evidences of their relation to natrocarbonatite activity. The composition of the groundmass carbonate of these lavas is significantly enriched in $\mathrm{Sr}$ compared to the other Catanda localities and also to the carbonate from altered natrocarbonatites worldwide (Fig. 9). Its isotopic values are also significantly different to the other Catanda lavas, especially in the case of carbon, which in the Huilala-Ungongue silicocarbonatites present a lighter composition (Fig. 10). The $\delta^{13} \mathrm{C} / \delta^{18} \mathrm{O}$ relation of the Huilala-Ungongué lavas is also different to the ratio reported for carbonatite localities worldwide and it follows the evolutionary trend related to magmatic degassing processes (Fig. 10). The explosive volcanic eruptions occurred in the area (Campeny et al., 2014) could explain the magmatic degassing which probably affected the HuilalaUngongué lavas. Hence, the groundmass of the Huilala-Ungongué silicocarbonatites contains periclase and calcite, which is a typical mineral association related to the decomposition of dolomite during degassing processes (Bucher and Frey, 1994). In summary, these lavas could be formed from primary dolomite bearing carbonatites affected by decarbonation during explosive eruptive processes, which produced the decomposition of dolomite to calcite and periclase. Suggesting a pre- or synemplacement differentiation, in contrast to post-emplacement differentiation in the other three suites.

\section{Conclusions}

1. Three different types of carbonatitic lavas have been described in the four different outcrops reported in the Catanda area: calciocarbonatites (Jango and Utihohala), silicocarbonatites (Huilala-Ungongué) and natrocarbonatites altered to secondary calciocarbonatites (Ipunda).

2. In Catanda, these three different types of lavas form a unique carbonatite suite, and are genetically related and generated from the same parental melt.

3. The melt inclusions assemblage hosted in magnetite grains is principally formed by alkali-rich phases, arguing for an alkaline composition of the Catanda parental melt. 
5. Catanda calciocarbonatite lavas present textural, compositional and isotopic features similar to those described in altered natrocarbonatite localities worldwide, such as Tinderet (Kenya) or Kerimasi (Tanzania). These resemblances plus the composition of original parental magmas extrapolated with melt inclusions indicate that Catanda calciocarbonatites represent the occurrence of natrocarbonatite magmatism in the area.

6. Silicocarbonatite lavas from the Huilala-Ungongué area present different mineralogical, compositional and isotopic features in comparison to the other Catanda lavas. Its formation would be related to primary dolomite bearing carbonatites affected by magmatic decarbonation and generating the present lavas which are enriched in calcite and periclase.

\section{Acknowledgements}

This research has been supported by the project CGL2009-13758 of the Spanish Government, the Australian Research Council and the projects SGR-589 and SGR-444 of the Generalitat de Catalunya. Logistics have been also funded by the scholarship program BE-DGR-2012 of the AGAUR (Agència de Gestió d'Ajuts Universitaris i Recerca) and the Hugh E. McKinstry fund, granted by the Society of Economic Geologists (SEG). Assistance during the fieldwork was provided by the Departamento de Geologia da Universidade Agostinho Neto from Luanda, Angola. We thank Joaquín Perona and Xavier Llobet from the Technical Centre of the University of Barcelona (CCiT) for their assistance for the stable isotopes and EPMA analyses respectively. We thank Paul Davidson from the CODES-ARC Centre of Excellence in Ore Deposits his kind help in the drafting and revision of this manuscript. We would also like to acknowledge the indispensable collaboration and the hospitality during the fieldwork of José Fortuna and Felipe Correia from the village of Catanda.

\section{References}

Bailey, D. K., Kearns, S. L., 2002. High-Ti magnetite in some fine-grained carbonatites and the magmatic implications. Min.Mag. 66 (3), 379-384.

Bambi, A.C.J.M, Costanzo, A., Gonçalves, A.O., Melgarejo, J.C., 2012. Tracing the chemical evolution of primary pyrochlore from plutonic to volcanic carbonatites: the role of fluorine. Mineral. Mag. 76, 393-409.

Barker, D.S., Nixon P.H., 1989. High-Ca, low-alkali carbonatite volcanism at Fort Portal, Uganda. Contrib. Mineral. Petrol. 103, 166-177.

Bell, K., Keller, J., (Eds.), 1995. Carbonatite Volcanism: Oldoinyo Lengai and the Petrogenesis of Natrocarbonatites. Springer-Verlag, Berlin, 210 pp. 
Bell, K., Simonetti, A., 2010. Source of parental melts to carbonatites critical isotopic constraints. Mineral. Petrol. 98, 77-89.

Boctor, N.Z., Boyd, F.R., 1982. Petrology of kimberlite from the DeBruyn and Martin Mine, Bellsbank, South Africa. Contrib. Mineral. Petrol. 76, 253-259.

Bucher, K., Frey, M., 1994. Petrogenesis of metamorphic rocks. Springer-Verlag, Berlin, $318 \mathrm{pp}$.

Calvo, A., Melgarejo, J.C., Bambi, A.C.J.M., Gonçalves, A.O., Alfonso, P., 2011. Nb and REE at the Bailundo carbonatite, Angola. In: Barra, F. (Ed.), Let's talk ore deposits. Ed. Universidad Católica del Norte, Antofagasta (Chile), pp. 675-677.

Calvo, A., Melgarejo, J.C., Alfonso, P., Bambi, A.C.J.M., Gonçalves, A.O., 2011. Nb and REE mobilization at the Longonjo carbonatite, Angola. In: Barra, F. (Ed.), Let's talk ore deposits. Ed. Universidad Católica del Norte, Antofagasta (Chile), pp. 681-683.

Campeny, M., Mangas, J., Melgarejo, J.C., Bambi, A., Alfonso, P., Gernon, T., Manuel, J., 2014. The Catanda extrusive carbonatites (Kwanza Sul, Angola): an example of explosive carbonatitic volcanism. Bulletin of Volcanology 76, 818-833.

Chakhmouradian, A.R., 2006. High-field-strength elements in carbonatitic rocks: Geochemistry, crystal chemistry and significance for constraining the sources of carbonatites. Chem. Geol. 235, 138-160.

Chakhmouradian, A.R., Wall, F., 2012. Rare earth elements: minerals, mines, magnets (and more). Elements 8 (5), 333-340.

Chen, W., Kamenetsky, V.S., Simonetti, A., 2013. Evidence for the alkaline nature of parental carbonatite melts at Oka complex in Canada. Nature Comm. 4, 2687.

Church, A.A., 1996. The petrology of the Kerimasi carbonatite volcano and the carbonatites of Oldoinyo Lengai with a review of other occurrences of extrusive carbonatites. PhD thesis, University of London. 384 pp.

Clark, M.G.C. and Roberts, B., 1986. Carbonated melilitites and calcitized alkali carbonatites from Homa Mountain, western Kenya: a reinterpretation. Geological Magazine 123, 683-692.

Dalou, C., Koga, T.K., Hammouda, T., Poitrasson, F., 2009. Trace element partitioning between carbonatitic melts and mantle transition zone minerals: Implications for the source of carbonatites. Geochimica et Cosmochimica Acta 73, 239-255.

Dawson, J.B., 1962a. The geology of Oldoinyo Lengai. Bulletin Volcanologique 24, 348387.

Dawson, J.B., 1962b. Sodium carbonate lavas from Oldoinyo Lengai, Tanganyika. Nature 195, 1075-1076.

Dawson, J.B., Keller, J., Nyamweru, C., 1995a. In: Bell, K., Keller, J. (Eds.), Historic and recent eruptive activity of Oldoinyo Lengai, pp. 4-22.

Dawson, J.B., Pinkerton, H., Norton, G.E., Pyle, D.M., Browning, P., Jackson, D., Fallick, A.E., 1995b. Petrology and geochemistry of Oldoinyo Lengai lavas extruded in November 1988: magma source, ascent and crystallization. In: Bell, K., Keller, J. (eds) Carbonatite Volcanism. Oldoinyo Lengai and the petrogenesis of 
natrocarbonatite IAVCEI Proceedings in Volcanology 4, 47-69.

Deans, T., Roberts, B., 1984. Carbonatite tuffs and lava clasts of the Tinderet foothills, western Kenya: a study of calcified natrocarbonatites. Journal of the Geological Society of London 141, 563-580.

Deines, P., 1989. Stable isotope variations in carbonatites. In: Bell, K. (ed) Carbonatites: Genesis and Evolution. Unwin Hyman, pp. 301-359.

Demény, A., Sitnikova, M.A., Karchevsky, P.I., 2004. Stable C and O isotope compositions of carbonatite complexes of the Kola Alkaline Province: phoscoritecarbonatite relationships and source compositions. In: Wall, F., Zaitsev, A.N. (Eds.), Phoscorites and Carbonatites from Mantle to Mine: the Key Example of the Kola Alkaline Province. Mineralogical Society, London, pp. 407-431.

Eby, G.N., Lloyd, F.E., Woolley, A.R., 2009. Geochemistry and petrogenesis of the Fort Portal, Uganda, extrusive carbonatite. Lithos 113, 785-800.

Guzmics, T., Mitchell, R.H., Szabo, C., Berkesi, M., Milke, R., Abart, R., 2011. Carbonatite melt inclusions in coexisting magnetite, apatite and monticellite in Kerimasi calciocarbonatite, Tanzania: melt evolution and petrogenesis. Contrib. Mineral. Petrol. 161, 177-196.

Habermann, D., Neuser, R.D., Richter, D.K., 1996. REE-activated cathodoluminescence of calcite and dolomite: high-resolution spectrometric analysis of CL emission (HRSCL). Sedimentary Geology 101, 1-7.

Hay, R.L., 1983. Natrocarbonatite tephra of Kerimasi volcano, Tanzania. Geology 11, 599-602.

Hornig-Kjarsgaard, I., 1998. Rare earth elements in sövitic carbonatites and their mineral phases. Journal of Petrology 39, 2105-2121.

Issa Filho, A., Dos Santos, A.B.R.M.D., Riffel, B.F., Lapido-Loureiro, F.E.V., McReath, I., 1991. Aspects of the geology, petrology and chemistry of some Angolan carbonatites. Journal of Geochemical Exploration 40, 205-226.

Kamenetsky, V.S., Kamenetsky, M.B., Sharygin, V.V., Golovin, A.V., 2007. Carbonatechloride enrichment in fresh kimberlites of the Udachnaya-East pipe, Siberia: A clue to physical properties of kimberlite magmas? Geophysical Research Letters 34 (9), L09316.

Kamenetsky, V.S., Golovin, A.V., Maas, R., Giuliani, A., Kamenetsky, M.B., Weiss, Y., 2014. Towards a new model for kimberlite petrogenesis: Evidence from unaltered kimberlites and mantle minerals. Earth-Science Reviews 139, 145-167.

Keller, J., 1981. Carbonatitic volcanism in the Kaiserstuhl alkaline complex: Evidence for highly fluid carbonatitic melts at the Earth's surface. Journal of Volcanology and Geothermal Research 9, 423-431.

Keller, J., Zaitsev, A.N., 2006. Calciocarbonatite dykes at Oldoinyo Lengai,Tanzania: the fate of natrocarbonatite. The Canadian Mineralogist 44, 857-876.

Keller, J., Zaitsev, A.N., 2012. Geochemistry and petrogenetic significance of natrocarbonatites at Oldoinyo Lengai, Tanzania: Composition of lavas from 1988 to 
2007. Lithos 148, 45-53.

Korolev, N.M., Marin, Y.B., Nikitina, L.P., Zinchenko, V.N., Chissupa, H.M., 2014. High_Nb Rutile from Upper Mantle Eclogite Xenoliths of the Diamond_Bearing Kimberlite Pipe Catoca (Angola). Doklady Akademii Nauk 454 (2), 207-210.

Mariano, A.N., Roedder, P.L., 1983. Kerimasi: a neglected carbonatite volcano. J. Geol. 91, 449-453.

McCrea, J.M., 1950. On the Isotopic Chemistry of Carbonates and a Paleotemperature Scale. The Journal of Chemical Physics 18 (6), 849-857.

Melgarejo, J.C., Costanzo, A., Bambi, A.C.J.M., Gonçalves, A.O., Neto, A.B., 2012. Subsolidus processes as a key factor on the distribution of $\mathrm{Nb}$ species in plutonic carbonatites: The Tchivira case, Angola. Lithos 152, 187-201.

Mitchell, R.H., 1986. Kimberlites: Mineralogy, Geochemistry and Petrology. New York: Plenum, $442 \mathrm{pp}$.

Mitchell, R.H., Belton, F., 2004. Niocalite-cuspidine solid solution and manganoan monticellite from natrocarbonatite, Oldoinyo Lengai, Tanzania. Mineral. Mag. 68 (5), 787-799.

Mitchell, R.H., Kamenetsky, V.S., 2012. Trace element geochemistry of nyerereite and gregoryite phenocrysts from natrocarbonatite lava, Oldoinyo Lengai, Tanzania: Implications for magma mixing. Lithos 152, 56-65.

Nixon, P.H., Hornung, G., 1973. The carbonatite lavas and tuffs near Fort Portal, western Uganda. Overseas Geology and Mineral Resources, Institute of Geological Sciences, London 41, 168-179.

Peres, A.M., Gomes, C.F., Cardoso-Simões, M.V., 1968. As variedades semi-preciosas de olivina da Catanda-Angola. Boletim dos Serviços de Geologia e Minas de Angola 18, 5-15.

Reguir, E.P. Chakhmouradian, A.R., Halden, N., Panseok, Y., Zaitsev, A.N., 2008 Early magmatic and reaction-induced trends in magnetite from the carbonatites of Kerimasi, Tanzania. Can. Mineral. 46 (4), 879-900.

Riley, T.R., Bailey, D.K., Lloyd, F.E., 1996. Extrusive carbonatite from the Quaternary Rockeskyll Complex, West Eifel, Germany. Can. Mineral. 34, 389-401.

Robles-Cruz, S.E., Escayola, M., Jackson, S., Galí, S., Pervov, V., Watangua, M., Gonçalves, A., Melgarejo, J.C., 2012. U-Pb SHRIMP geochronology of zircon from the Catoca kimberlite, Angola: Implications for diamond exploration. Chem. Geol 310-311, 137-147.

Rozova, Y.V., Frantsesson, E.V., Pleshakov, A.P., Botova, M.M., Filipova, L.P., 1982. High iron chrome spinels in kimberlites of Yakutia. Int. Geol. Rev. 24, 1417-1425.

Santos, R.V., Clayton, R.N., 1995. Variations of oxygen and carbon isotopes in carbonatites: A study of Brazilian alkaline complexes. Geochimica et Cosmochimica Acta 59 (7), 1339-1352.

Sharygin, V.V., Kamenetsky, V.S., Kamenetsky, M.B., 2008. Potassium sulfides in kimberlite-hosted chloride-"nyerereite" and chloride clasts of Udachnaya-East Pipe, 
Yakutia, Russia. Can. Mineral. 46, 1079-1095.

Sharygin, V.V., Kamenetsky, V.S., Zaitsev, A.N., Kamenetsky, M.B., 2012. Silicatenatrocarbonatite liquid immiscibility in 1917 eruption combeite-wollastonite nephelinite, Oldoinyo Lengai Volcano, Tanzania: Melt inclusion study. Lithos 152, 23-39.

Silva, M.V.S., Pereira, E., 1973. Estrutura Vulcânico-Carbonatitica da Catanda (Angola). Boletim dos Serviços de Geologia e Minas de Angola 24, 5-14.

Sun, S., McDonough, W.F., 1989. Chemical and isotopic systematics of oceanic basalts: implications for mantle composition and processes. In: Saunders, A.D., Norry, M.J. (Eds.), Magmatism in the oceanic basins. Geological Society of London, Spec. Publ. 42, 313-345.

Sun, C., Liang, Y., 2013. The importance of crystal chemistry on REE partitioning between mantle minerals (garnet, clinopyroxene, orthopyroxene, and olivine) and basalt melts. Chemical Geology 358, 23-36.

Tappe, S., Foley, S., Jenner, G.A., Kjarsgaard, B.A., 2005. Integrating Ultramafic Lamprophyres into the IUGS Classification of Igneous Rocks: Rationale and Implications. Journal of Petrology 46 (9), 1893-1900.

Tappe, S., Foley, S.F., Jenner, G.A., Heaman, L.M., Kjarsgaard, B.A., Romer, R.L., Stracke, A., Joyce, N., Hoefs, J., 2006. Genesis of ultramafic lamprophyres and carbonatites at Aillik Bay, Labrador: a consequence of incipient lithospheric thinning beneath the North Atlantic Craton. Journal of Petrology 47 (7), 1261-1315.

Tappe, S., Foley, S.F., Kjarsgaard, B.A., Romer, R.L., Heaman, L.M., Strackle, A., Jenner, G.A., 2008. Between carbonatite and lamproite-Diamondiferous Torngat ultramafic lamprophyres formed by carbonate-fluxed melting of cratonic MARIDtype metasomes. Geochimica et Cosmochimica Acta 72 (13), 3258-3286.

Tappe, S., Steenfelt, A., Heaman, L.M., Simonetti, A., 2009. The newly discovered Jurassic Tikiusaaq carbonatite-aillikite occurrence, West Greenland, and some remarks on carbonatite-kimberlite relationships. Lithos 112S, 385-399.

Taylor, H.P., Frechen, J., Degens, E.T., 1967. Oxygen and carbonisotope studies of carbonatites from the Laacher See District, West Germany and the Alnö District, Sweden. Geochimica et Cosmochimica Acta 31, 407-430.

Torquato, J.R., Amaral, G., 1973. Algumas idades K/Ar do magmatismo mesozóico de Angola e sua correlação com o correspondente do sul do Brasil. Boletim do Instituto de Investigação Científica de Angola 10, 31-38.

Torró, L., Villanova, C., Castillo, M., Campeny, M., Gonçalves, A.O., Melgarejo, J.C., 2012. Niobium and rare earth minerals from the Virulundo carbonatite, Namibe, Angola. Mineral. Mag. 76, 393-409.

van Westrenen, W., Blundy, J., Wood, B., 1999. Crystal chemical controls on trace element partitioning between garnet and anhydrous silicate melt. American Mineralogist 84, 838-847.

von Knorring, O., Du Bois, C.G.B., 1961. Carbonatitic lava from Fort Portal area in western Uganda. Nature 192, 1064-1065. 
Wallace, M. E., Green, D. H., 1988. An experimental determination of primary carbonatite magma composition. Nature 335, 343-346.

Wiedenmann, D., Keller, J., Zaitsev A.N., 2010. Melilite-group minerals at Oldoinyo Lengai, Tanzania. Lithos 118, 112-118.

Woolley, A.R., 2001. Alkaline rocks and carbonatites of the world. Part 3: Africa. Geological Society of London, London, 372 pp.

Woolley, A.R., Church, A.A., 2005. Extrusive carbonatites: A brief review. Lithos 85, 114.

Woolley, A.R., Kjarsgaard, B.A., 2008. Carbonatites of the world: map and database. Mineral. Mag. 71, 718.

Zaitsev, A.N., Keller, J., 2006. Mineralogical and chemical transformation of Oldoinyo Lengai natrocarbonatites, Tanzania. Lithos 91, 191-207.

Zaitsev, A.N., Wenzel, T., Venneman, T., Markl, G., 2013. Tinderet volcano, Kenya: an altered natrocarbonatite locality?. Mineral. Mag. 77 (3), 213-226.

\section{FIGURES}

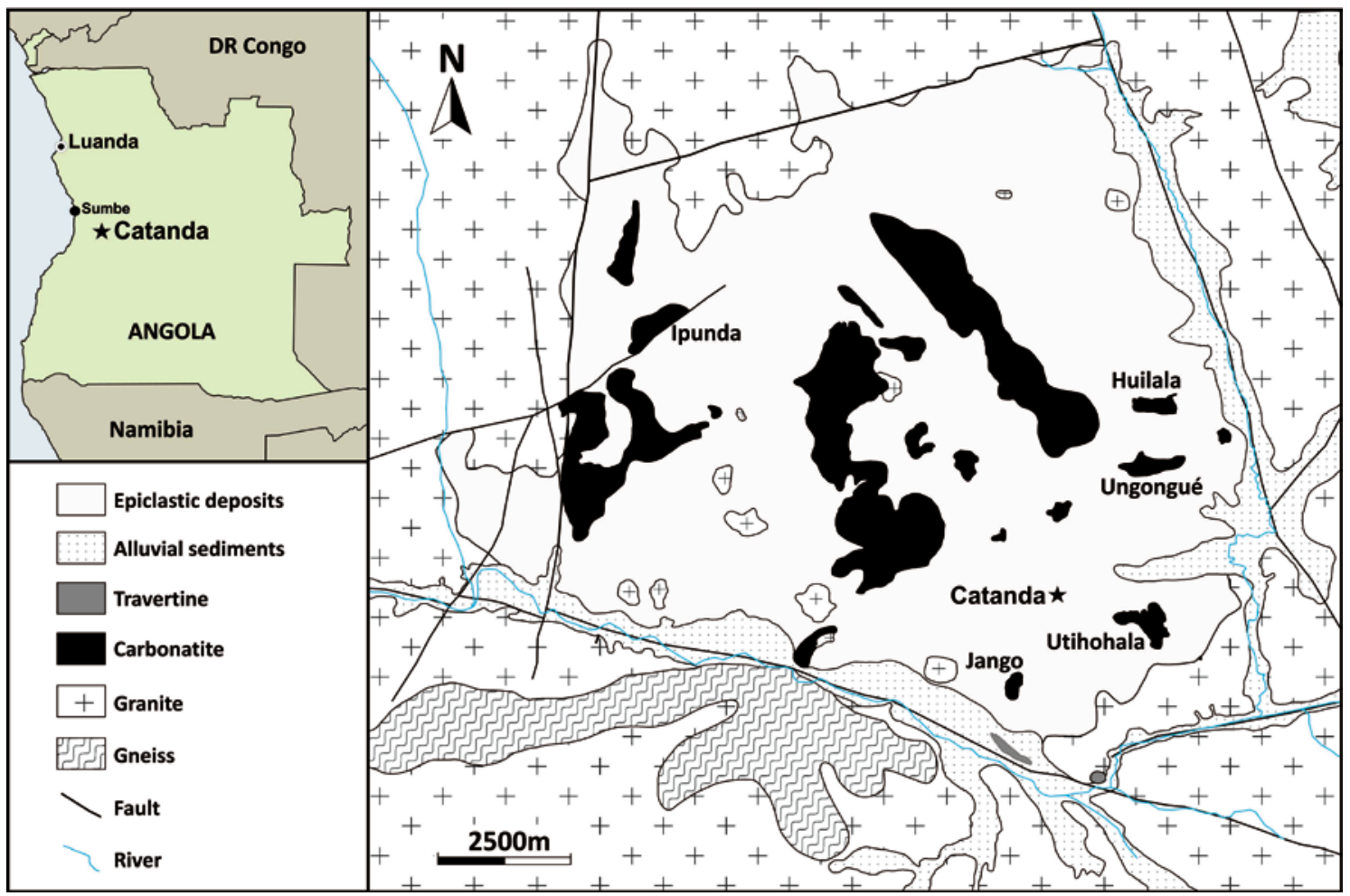

Fig.1. Geographic location and geological map of the Catanda area. 

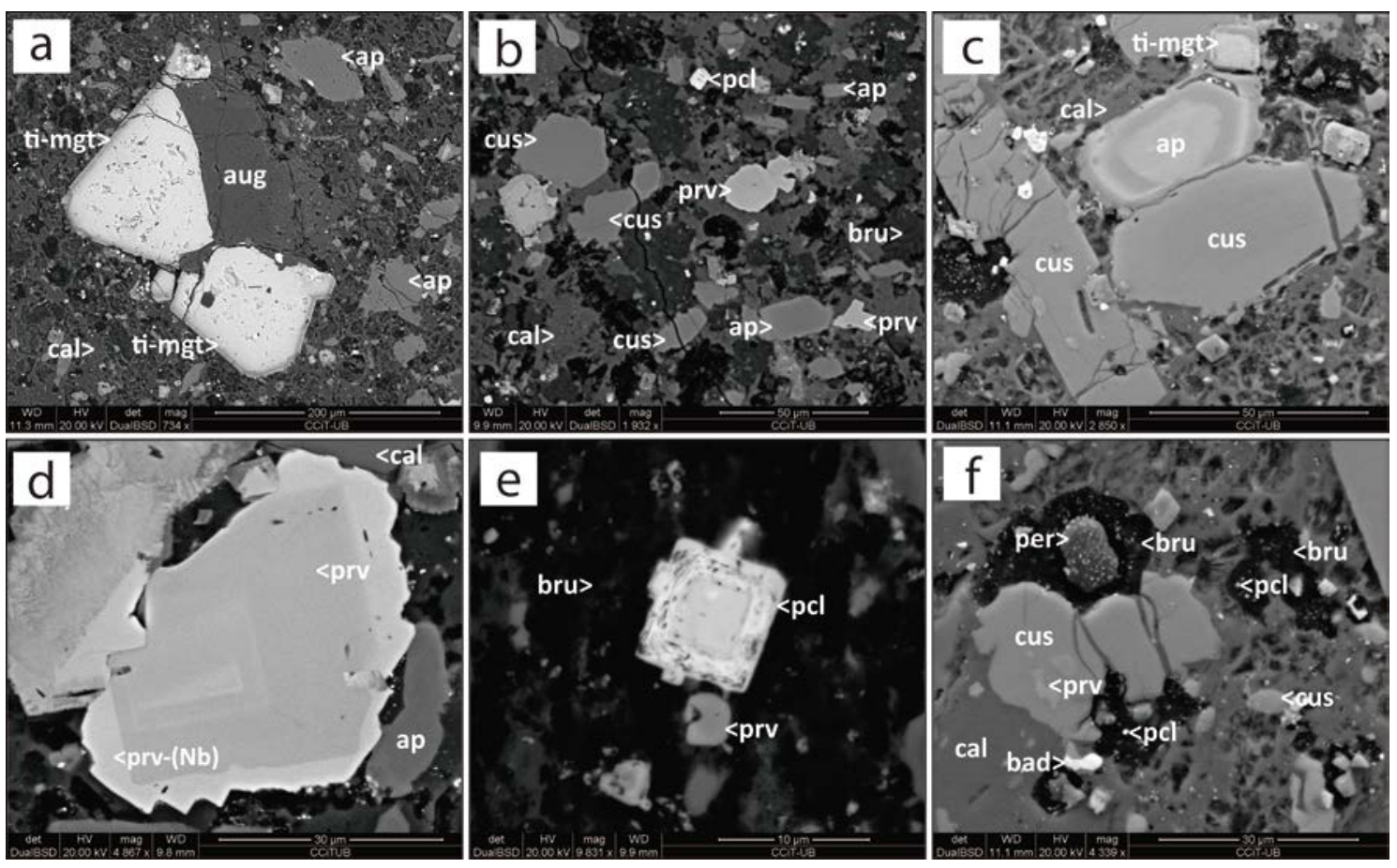

Fig.2. SEM (BSE) images of the Huilala-Ungongué lavas. a Microphenocrysts of fluorapatite (ap) and titaniferous magnetite (ti-mgt) partially replaced by augite (aug) which also infill small fractures. b Typical mineral association of the HuilalaUngongué groundmass: fluorapatite (ap), cuspidine (cus), pyrochlore (pcl), perovskite (prv), fine grained calcite (cal) and secondary brucite (bru). c Basal section of zoned fluorapatite (ap) associated with euhedral grains of cuspidine (cus) and titaniferous magnetite (ti-mgt). d Euhedral crystal of perovskite showing extreme compositional zoning with rims enriched in $\mathrm{Nb}$. e Euhedral grains of zoned pyrochlore (pcl) and perovskite (prv) inside a typical halo of brucite (bru). $\mathbf{f}$ Preserved grain of periclase (per) surrounded by secondary brucite (bru) associated with cuspidine (cus) with perovskite (prv) and baddeleyite inclusions. Small grains of pyrochlore are also present inside the brucite halos. 

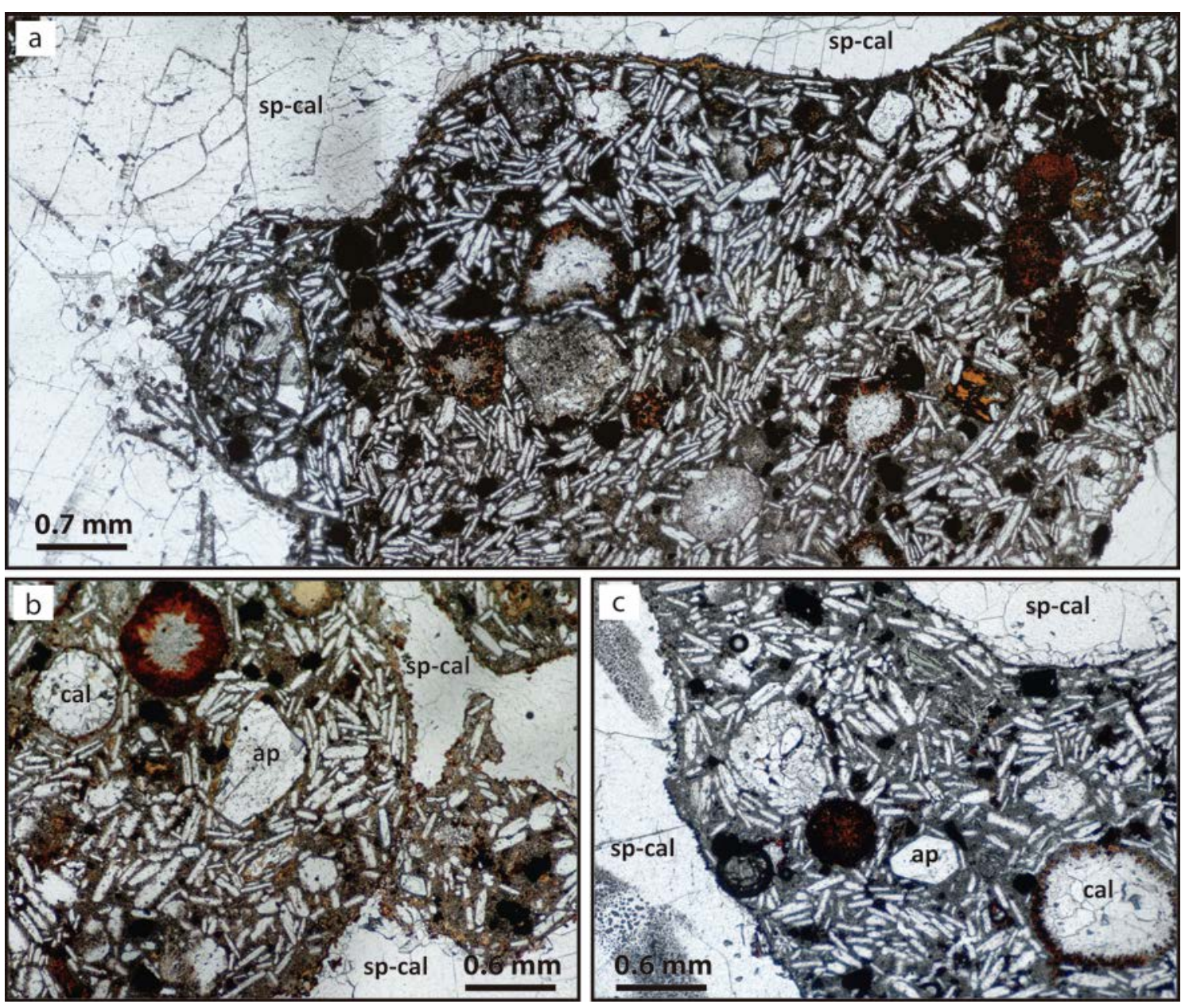

Fig.3. Plane-polarized light photomicrographs of Ipunda lavas. a General view of a Ipunda lava sample distinguished by its distinctive trachytoidal texture of tabular calcite phenocrysts. Secondary sparry calcite (sp-cal) is also present. b Ipunda lava with fluorapatite (ap) phenocrysts and spherical globules filled by calcite (cal). c Euhedral phenocryst of apatite (ap) accompanied by tabular calcite and typical spherical globules filled with calcite (cal) and secondary iron oxides. 

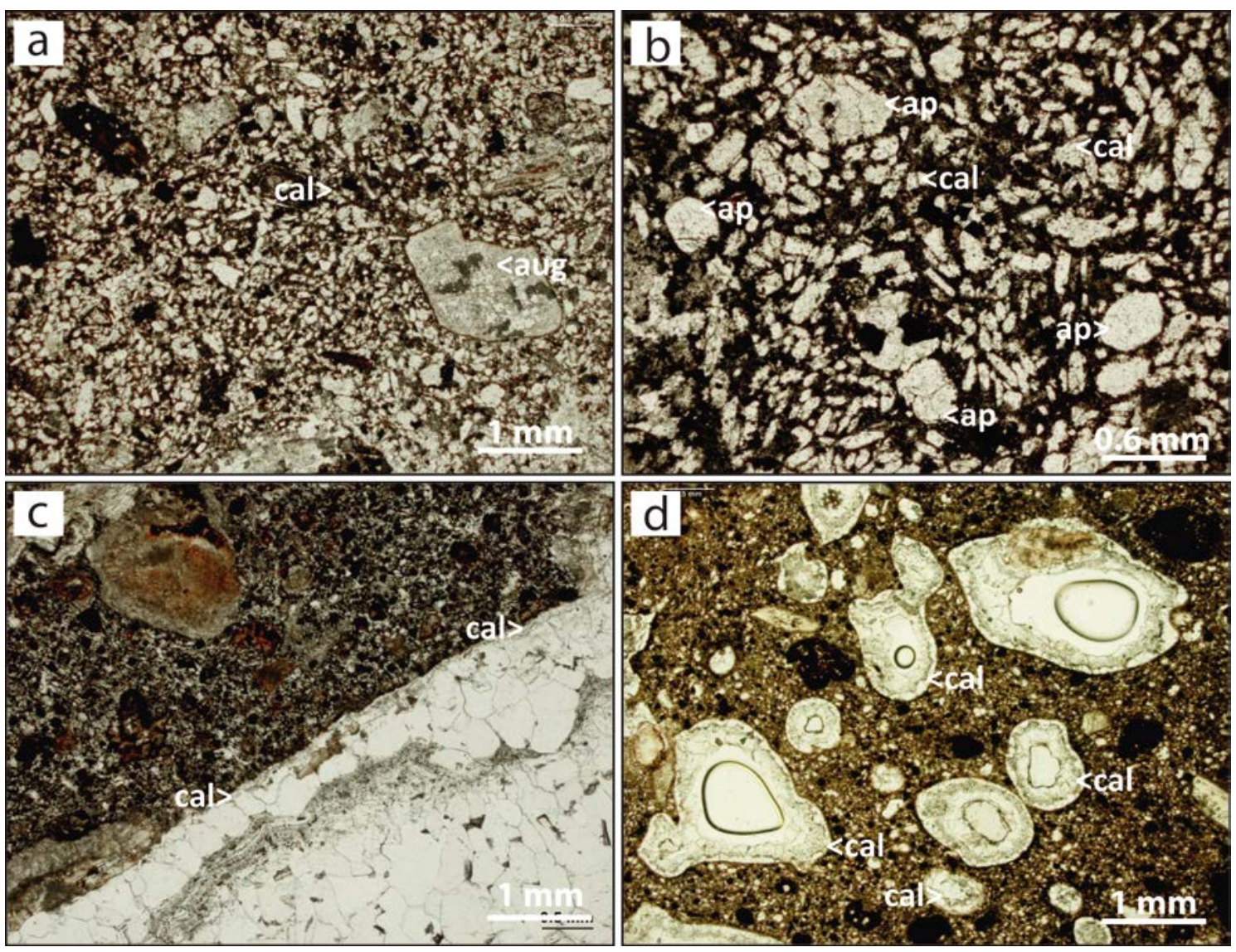

Fig.4. Plane-polarized light photomicrographs of the Utihohala and Jango lavas a General view of a Utihohala sample. Augite (aug) microphenocrysts in calcitic (cal) groundmass. b Subhedral grains of fluorapatite (ap) and calcite (cal) in the Utihohala lava groundmass. c General view of the Jango lava sample with secondary calcite (cal) infilling a fracture. d Jango lava sample with typical cavities partially infilled by secondary calcite (cal). 

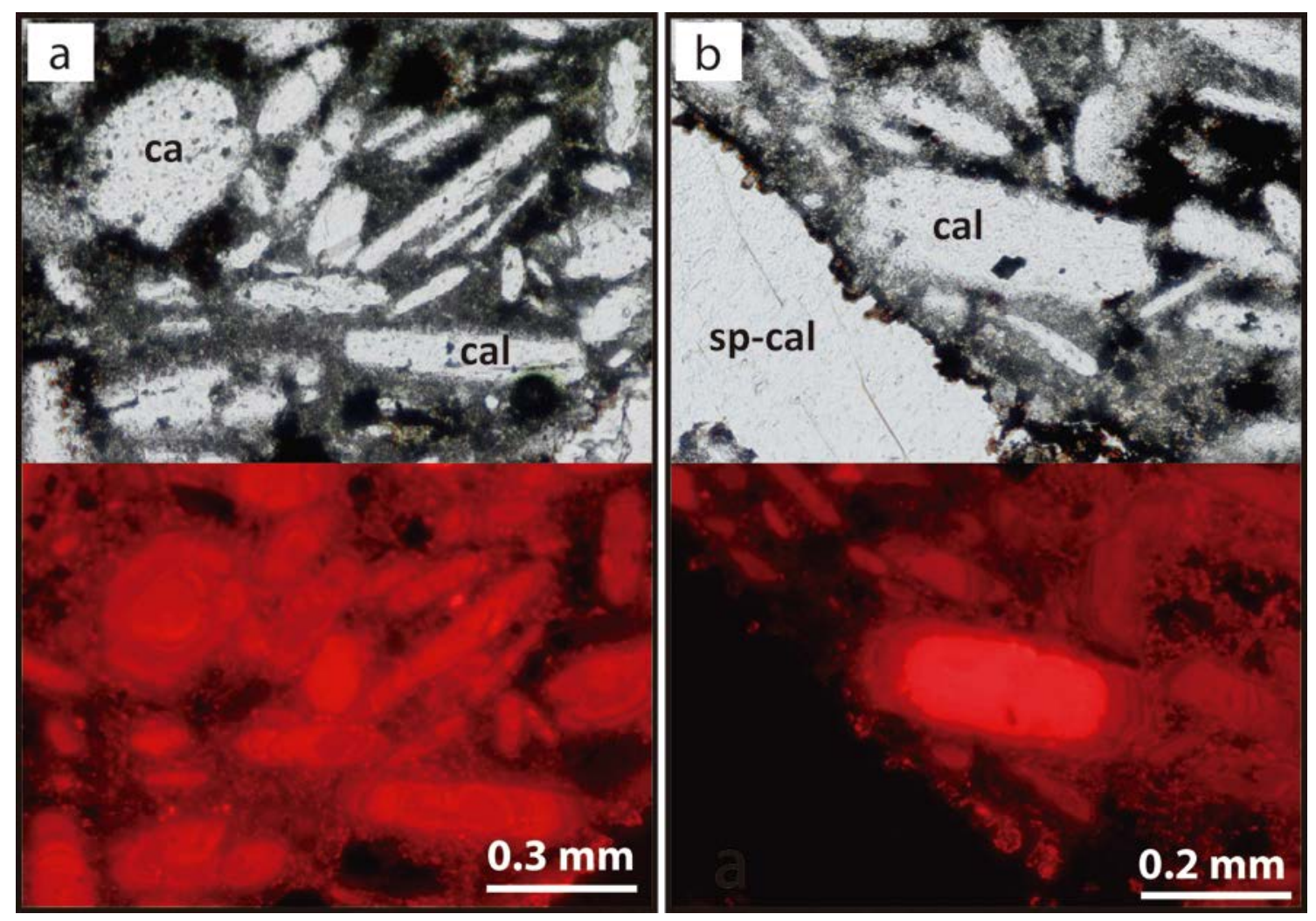

Fig.5. a Ipunda sample. Euhedral fluorapatite (ap) section and tabular crystals of calcite (cal). Cathodoluminiscence response of calcite is distinguished by a marked orange glow and fluorapatite exhibits concentric zoning. b Tabular phenocrysts of calcite (cal) show a marked zoning under cold cathodoluminiscence while secondary sparry calcite (sp-cal) does not exhibit any response at all. 


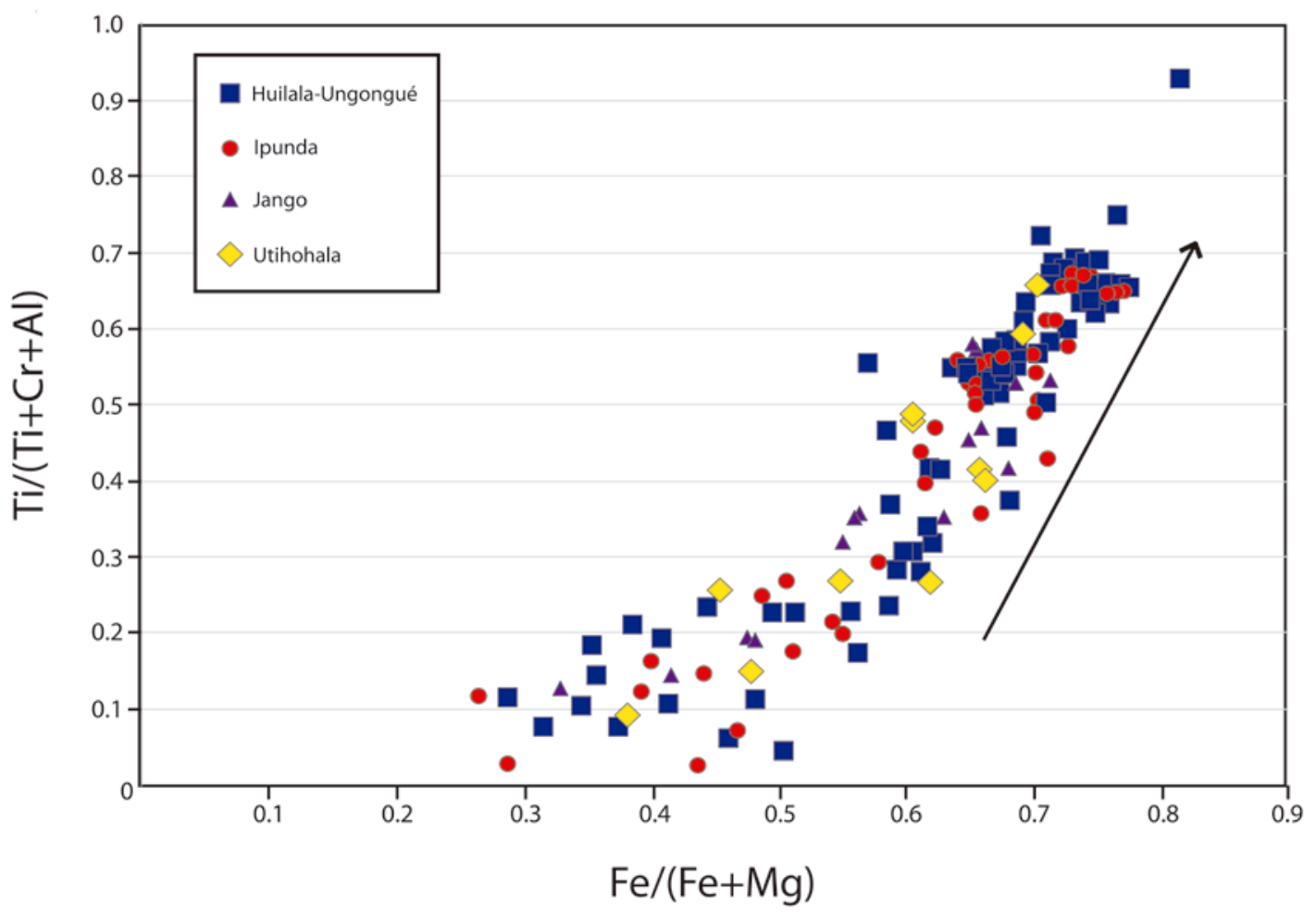

Fig.6. Relation between $\mathrm{Fe} /(\mathrm{Fe}+\mathrm{Mg})$ and $\mathrm{Ti} /(\mathrm{Ti}+\mathrm{Cr}+\mathrm{Al})$ in the Catanda magnetite showing a typical "titanomagnetite trend" according to Mitchell (1986). 

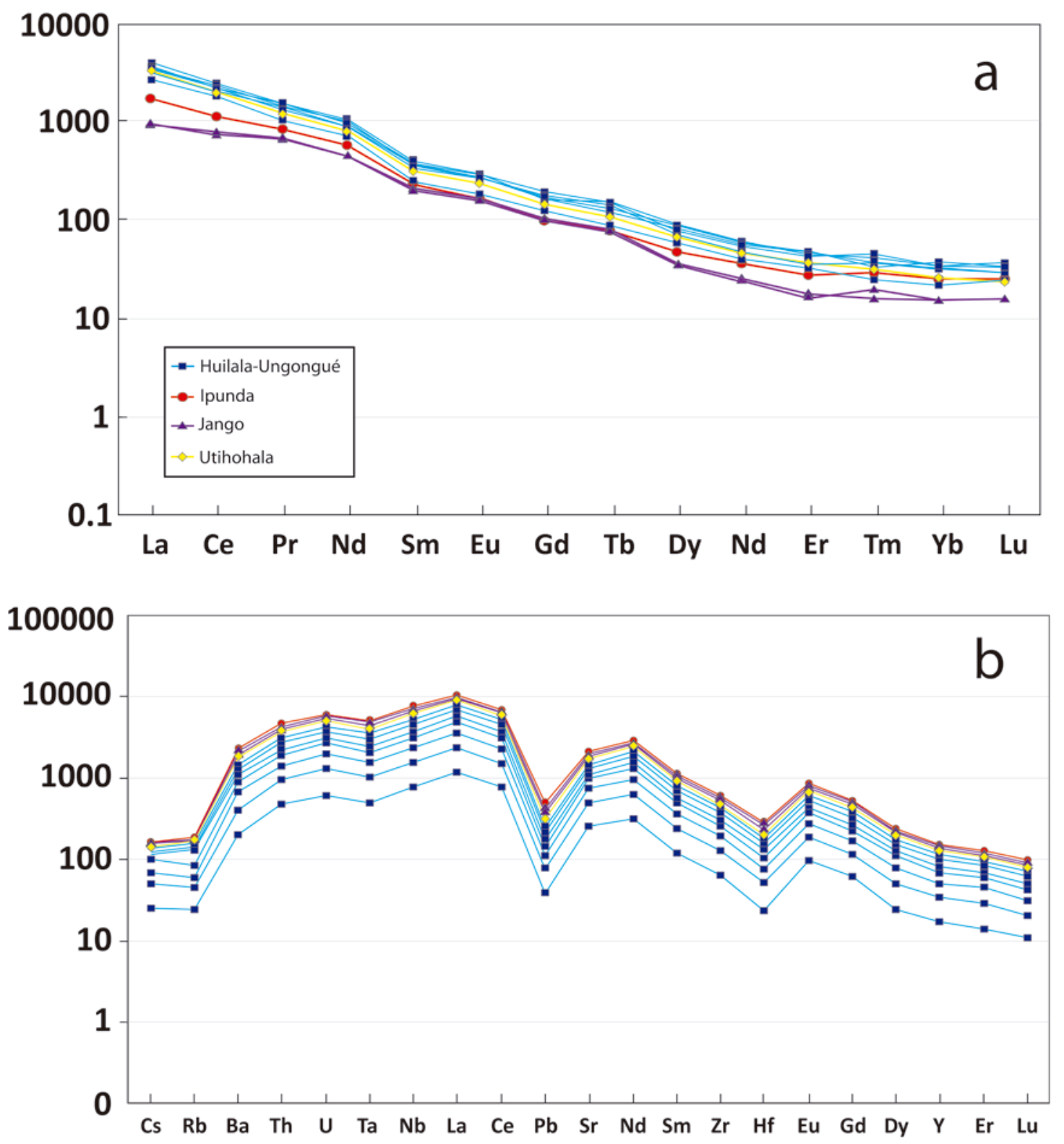

Fig. 7. a REE plot of Catanda carbonatite lavas normalized to chondrite. b Multielemental trace element composition of Catanda carbonatite lavas normalized to primitive mantle. Normalization values in both diagrams from Sun and McDonough (1989). 

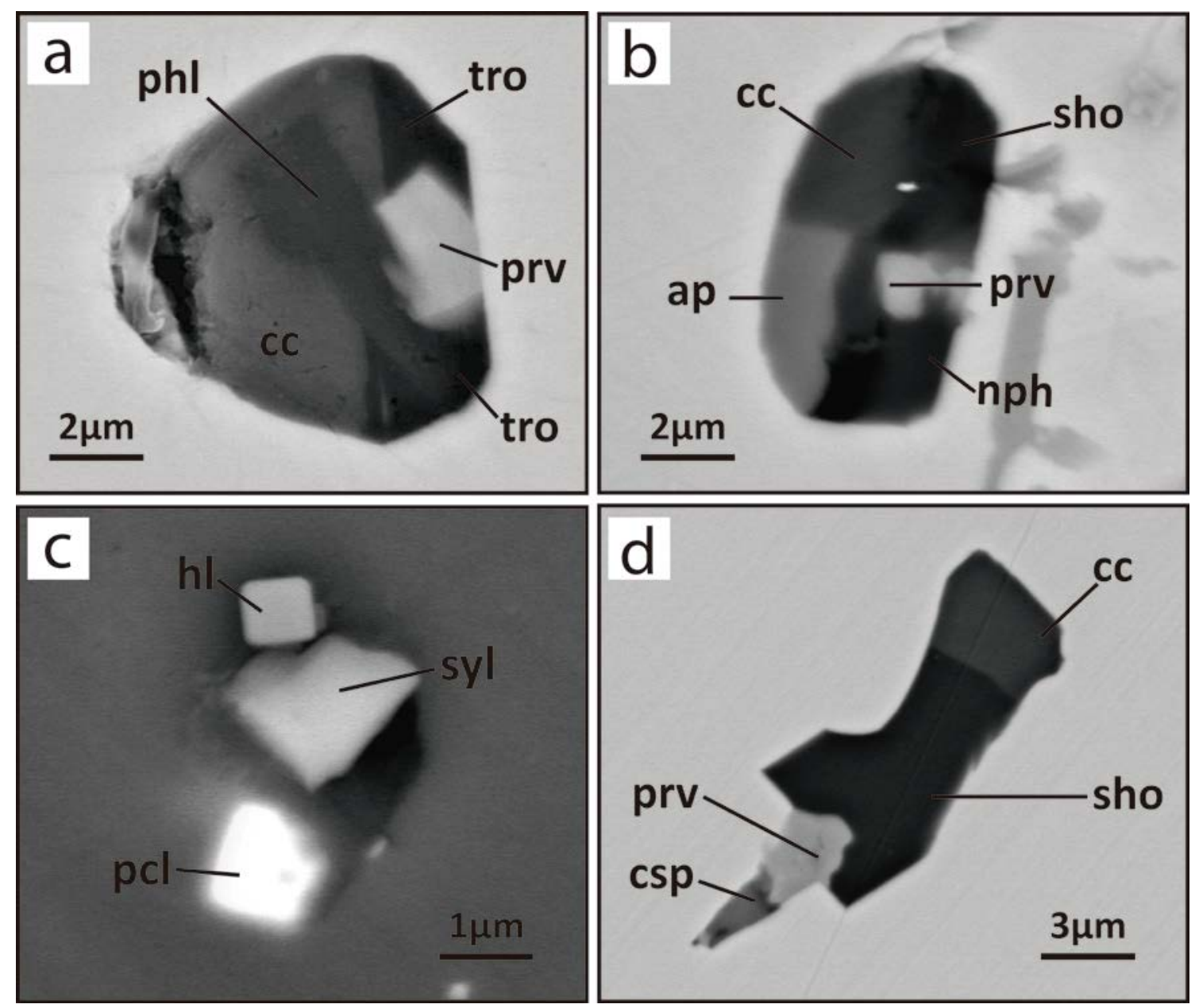

Fig. 8. SEM (BSE) images of melt inclusions in magnetite of Catanda lavas. a Alkaline and calcium carbonates, trona (tro) and calcite (cal), coexisting in the same melt inclusion, accompanied by perovskite (prv) and a tabular crystal of phlogopite (phl). b Silicate-carbonate inclusion with nepheline (nph) and shortite (sho) associated with calcite (cal), fluorapatite (ap) and perovskite (prv). c Melt inclusion containing daughter crystals of sylvite (syl), halite (hl) and pyrochlore (pcl). d Calcite (cal) associated with alkaline carbonate (shortite [sho]) in assemblage with perovskite (prv) and cuspidine (csp). 


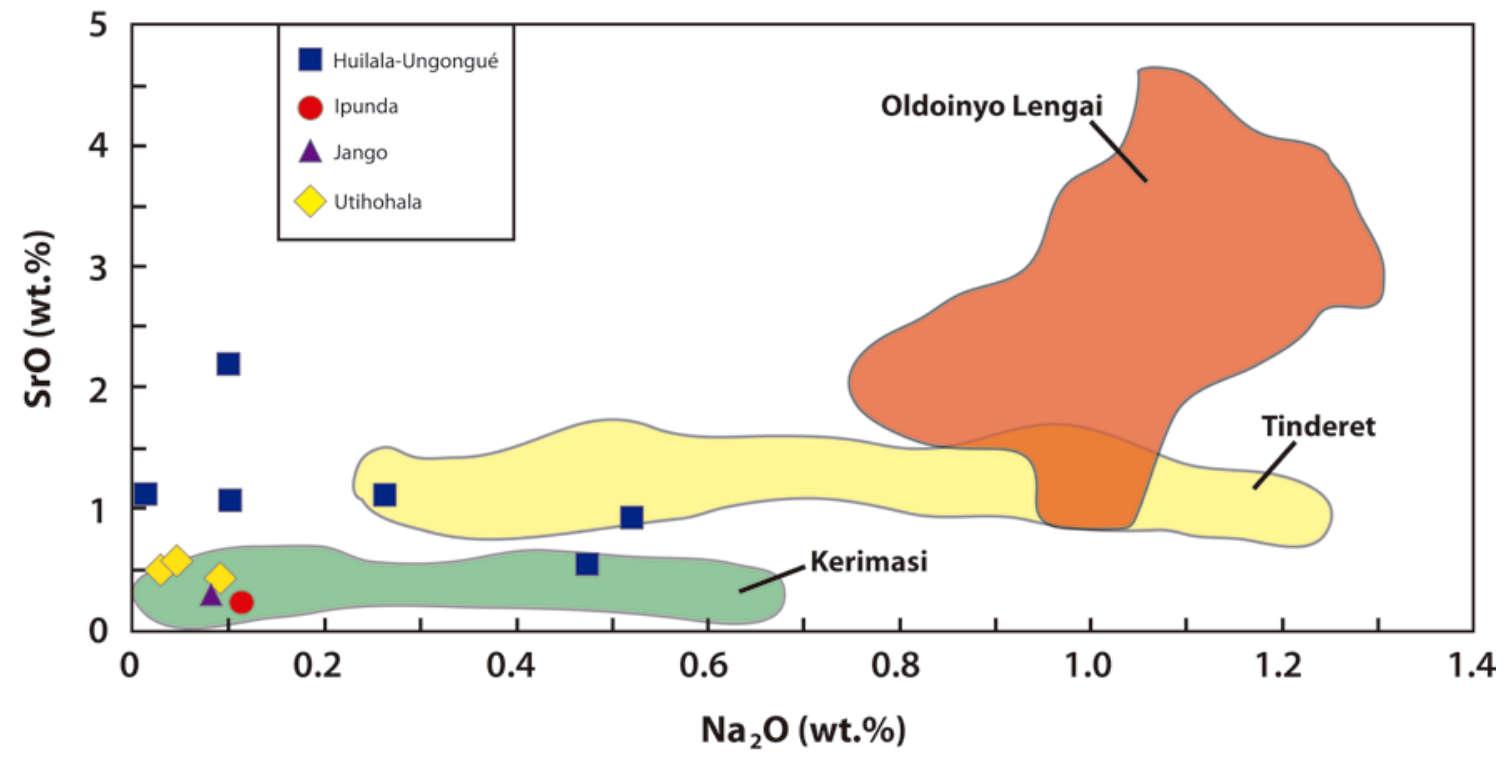

Fig. 9. Catanda carbonates $\mathrm{SrO}$ and $\mathrm{N}_{2} \mathrm{O}$ composition compared to natrocarbonatite localities worldwide. Values obtained from Zaitsev et al. 2013.

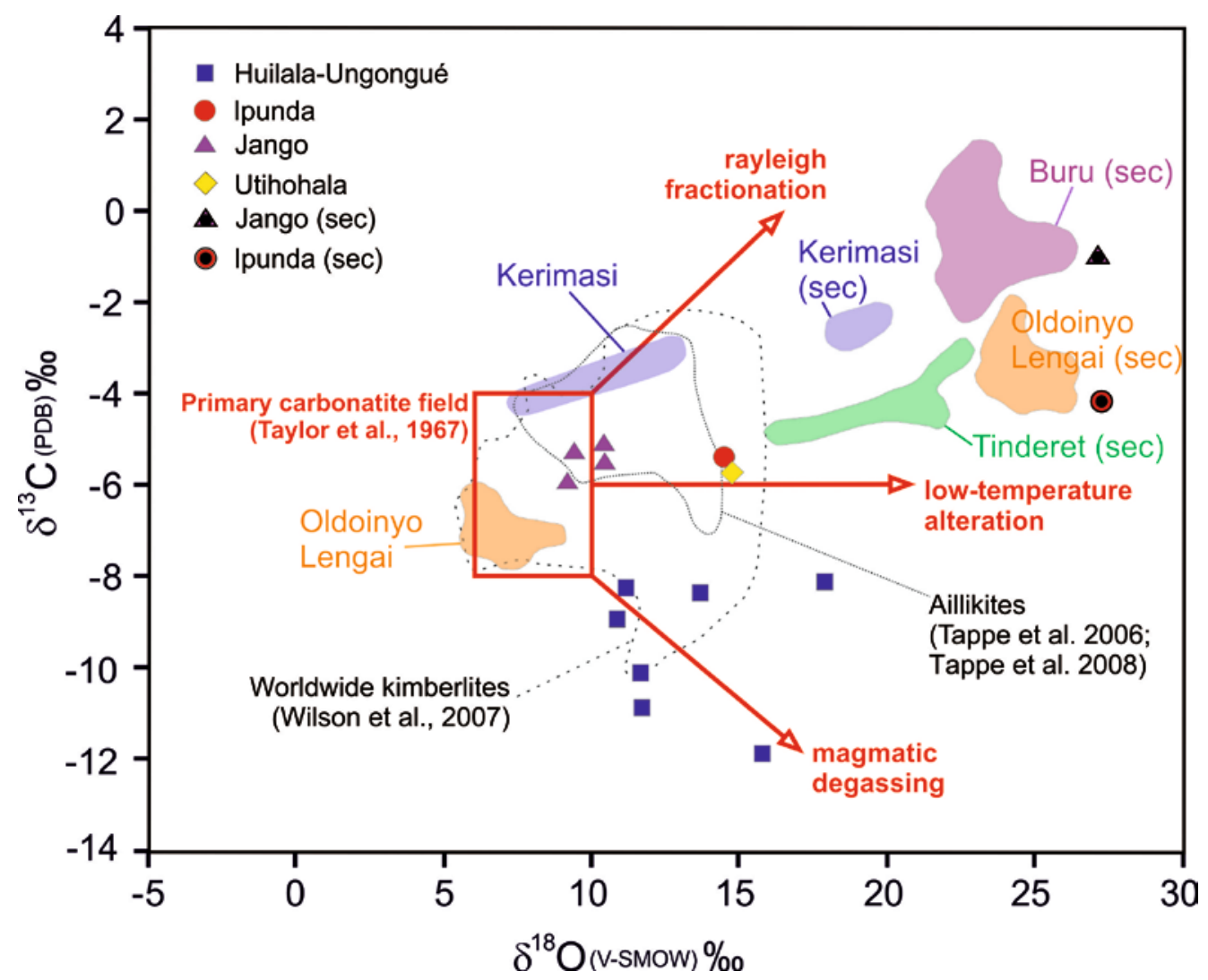

Fig. 10. Graphical comparison of the isotopic composition $\left(\delta^{13} \mathrm{C}\right.$ and $\left.\delta^{18} 0\right)$ of the Catanda primary and secondary carbonates with other carbonatite and natrocarbonatite localities. Data obtained from Zaitsev et al. 2013. Red arrows indicate trends of isotopic evolution (Demény et al., 2004). 


\section{TABLES}

Table 1. Mineralogical and textural comparison of the different carbonatite lava locations reported in the Catanda area.

\begin{tabular}{|c|c|c|c|}
\hline Location & Texture & $\begin{array}{l}\text { Carbonate content } \\
\text { (modal \%) }\end{array}$ & Mineralogy \\
\hline Huilala - Ungongué & Finely porphyritic & $\sim 30$ & $\begin{array}{l}\text { Microphenocrysts: fluorapatite ( } 35 \%) \text {, titaniferous } \\
\text { magnetite ( } 35 \%) \text {, augite ( } 15 \%) \text {, phlogopite }(15 \%) \\
\text { Groundmass: calcite, fluorapatite, titaniferous magnetite, } \\
\text { pyrochlore, baddeleyite, cuspidine, perovskite, periclase, } \\
\text { brucite, zirconolite, spurrite, oldhamite } \\
\text { Xenocrysts: olivine, quartz, microcline } \\
\text { Secondary: sparry calcite, barite, rabdophane, crandallite }\end{array}$ \\
\hline Ipunda & Trachytoid & $\sim 70$ & $\begin{array}{l}\text { Microphenocrysts: calcite (60\%), fluorapatite (15\%), } \\
\text { titaniferous magnetite (15\%), phlogopite ( } 5 \%) \text {, augite ( } 5 \%) \\
\text { Groundmass: calcite, fluorapatite, titaniferous magnetite, } \\
\text { pyrochlore, baddeleyite } \\
\text { Xenocrysts: quartz, microcline } \\
\text { Secondary: sparry calcite }\end{array}$ \\
\hline Jango & Finely porphyritic & $\sim 70$ & $\begin{array}{l}\text { Phenocrysts: fluorapatite }(60 \%) \text {, titaniferous magnetite } \\
(25 \%) \text {, phlogopite }(10 \%) \text {, augite }(5 \%) \\
\text { Groundmass: calcite, fluorapatite, titaniferous magnetite, } \\
\text { pyrochlore, baddeleyite, monticellite } \\
\text { Xenocrysts: amphibole, quartz, microcline } \\
\text { Secondary: sparry calcite }\end{array}$ \\
\hline Utihohala & Finely porphyritic & $\sim 60$ & $\begin{array}{l}\text { Microphenocrysts: fluorapatite }(60 \%) \text {, titaniferous } \\
\text { magnetite }(20 \%) \text {, phlogopite }(15 \%) \text {, augite (5\%) } \\
\text { Groundmass: calcite, fluorapatite, titaniferous magnetite, } \\
\text { pyrochlore, alabandite } \\
\text { Xenocrysts: quartz, microcline } \\
\text { Secondary: sparry calcite }\end{array}$ \\
\hline
\end{tabular}


Table 2. LA-ICPMS analyses: composition of the Catanda lavas primary carbonate.

\begin{tabular}{|c|c|c|c|c|c|c|c|c|c|c|c|c|c|}
\hline \multirow[b]{2}{*}{$\begin{array}{r}\text { Sample } \\
\text { ppm }\end{array}$} & \multicolumn{8}{|c|}{ Huilala - Ungongué } & \multirow{2}{*}{$\begin{array}{l}\text { Ipunda } \\
\underline{\mathrm{AC}-18}\end{array}$} & \multicolumn{3}{|l|}{ Jango } & \multirow{2}{*}{$\begin{array}{l}\text { Utihohala } \\
\underline{\mathrm{AC}-17}\end{array}$} \\
\hline & $\underline{A C-19}$ & $\underline{A C-20}$ & AC-21 & AC-24 & AC-25 & AC-35 & $\underline{A C-36}$ & AC-38 & & $\underline{A C-39}$ & AC-40 & AC-41 & \\
\hline $\mathrm{Na}$ & 3524 & 773.9 & 3886.2 & 1944.9 & 765.8 & 294.7 & 109.9 & 2.7 & 836.1 & 233.1 & 327.7 & 683.9 & 606.1 \\
\hline K & 2970.3 & 597.5 & 851.4 & 2188.7 & 5485.6 & 49.6 & 59.3 & 0,0 & 104.3 & 49.4 & 110.8 & 129.8 & 183.9 \\
\hline $\mathrm{Rb}$ & 49.2 & 36.4 & 16.6 & 12 & 375.1 & 0 & 0.2 & 0 & 0.9 & 0.1 & 0.2 & 0.4 & 0.4 \\
\hline $\mathrm{Sr}$ & 4764.3 & 9096.6 & 8067.9 & 9563.4 & 18758.5 & 4759.1 & 9355.7 & 210.1 & 2103.6 & 4230.3 & 5168.8 & 3754.9 & 2820.1 \\
\hline$Y$ & 97.1 & 9.2 & 129.1 & 22.4 & 0.9 & 59.6 & 14.6 & 0.3 & 0.2 & 0.3 & 15.8 & 33.4 & 0.1 \\
\hline $\mathrm{Nb}$ & 346.9 & 8.2 & 489.9 & 70.4 & 0.1 & 0.1 & 35,0 & 2.0 & 0.2 & 0.1 & 23.1 & 477.9 & 0 \\
\hline Mo & 66.9 & 0.9 & 8.8 & 1.1 & 0.3 & 0 & 0.6 & 0 & 0.4 & 0 & 0.1 & 0.3 & 0.1 \\
\hline $\mathrm{Cd}$ & 0.3 & 0.1 & 0.6 & 0.1 & 3.1 & 0.1 & 0.1 & 0 & 0 & 0 & 0 & 0 & 0 \\
\hline $\mathrm{Ba}$ & 1282.2 & 3076.4 & 1639.7 & 6326.2 & 2082.6 & 269 & 627.4 & 11.5 & 6335.3 & 3479.7 & 1444.9 & 933.7 & 4217.6 \\
\hline La & 763.4 & 19.7 & 1190.8 & 98.5 & 6.9 & 333.4 & 124.6 & 0.9 & 0.3 & 3.5 & 153.3 & 268.7 & 0.4 \\
\hline $\mathrm{Ce}$ & 1130.9 & 30.6 & 2087.9 & 174.2 & 7.2 & 661.9 & 203.5 & 1.5 & 0.3 & 2.1 & 244.9 & 568.5 & 0.4 \\
\hline $\operatorname{Pr}$ & 100.3 & 3.6 & 205.4 & 18.2 & 0.7 & 74,0 & 23.2 & 0.1 & 0 & 0.4 & 31.1 & 62.7 & 0,0 \\
\hline $\mathrm{Nd}$ & 322.4 & 14.9 & 717.5 & 67.7 & 2.4 & 283.4 & 83.4 & 0.3 & 0.1 & 1.6 & 116.7 & 242.8 & 0.1 \\
\hline $\mathrm{Sm}$ & 44.7 & 2.6 & 93.3 & 10.8 & 0.3 & 40,0 & 11.4 & 0 & 0 & 0.2 & 16.1 & 34.6 & 0 \\
\hline $\mathrm{Eu}$ & 11.9 & 0.9 & 24.1 & 3 & 0.1 & 10.7 & 3.0 & 0 & 0.1 & 0.1 & 4.7 & 8.6 & 0 \\
\hline $\mathrm{Gd}$ & 32.2 & 2.2 & 62.3 & 8.7 & 0.2 & 27,0 & 7.2 & 0 & 0 & 0.2 & 9.9 & 21.3 & 0 \\
\hline $\mathrm{Tb}$ & 3.7 & 0.3 & 6.4 & 0.9 & 0 & 3 & 0.8 & 0 & 0 & 0 & 0.9 & 2.0 & 0 \\
\hline Dy & 19.4 & 1.5 & 30.7 & 4.8 & 0.1 & 13.6 & 3.6 & 0 & 0 & 0.1 & 3.8 & 8.8 & 0 \\
\hline $\mathrm{Ho}$ & 3.4 & 0.2 & 4.9 & 0.8 & 0 & 2.2 & 0.6 & 0 & 0 & 0 & 0.5 & 1.3 & 0 \\
\hline $\mathrm{Er}$ & 8.3 & 0.7 & 11.4 & 2 & 0.1 & 4.9 & 1.3 & 0 & 0 & 0 & 1.2 & 2.9 & 0 \\
\hline $\mathrm{Tm}$ & 1 & 0.1 & 1.2 & 2 & 0 & 0.5 & 0.1 & 0 & 0 & 0 & 0.1 & 0.3 & 0 \\
\hline $\mathrm{Yb}$ & 6.5 & 0.7 & 7.2 & 1.5 & 0 & 3.1 & 0.9 & 0 & 0 & 0 & 0.8 & 1.7 & 0 \\
\hline Lu & 0.9 & 0.1 & 0.9 & 0.2 & 0 & 0.4 & 0.1 & 0 & 0 & 0 & 0.1 & 0.2 & 0 \\
\hline $\mathrm{Hf}$ & 4 & 0.6 & 5.3 & 2.4 & 0 & 0 & 0 & 0 & 0 & 0 & 0.1 & 7.3 & 0 \\
\hline $\mathrm{Ta}$ & 7.4 & 0.3 & 19.7 & 2.9 & 0 & 0 & 0.3 & 0 & 0 & 0 & 0.8 & 21.2 & 0 \\
\hline $\mathrm{Pb}$ & 15.5 & 3.9 & 30.3 & 0.1 & 4.7 & 0.8 & 2.8 & 0.4 & 0.2 & 0 & 5.2 & 5.4 & 0 \\
\hline Th & 7.4 & 0 & 62 & 1.7 & 0.1 & 0.4 & 3.2 & 0 & 0 & 0 & 3.0 & 31.6 & 0 \\
\hline $\mathrm{U}$ & 9.9 & 0.6 & 17 & 9.6 & 0 & 0 & 1.3 & 0.1 & 0 & 0 & 0.3 & 11.6 & 0 \\
\hline
\end{tabular}

Table 3. EPMA analyses: composition of the spinel group minerals from Catanda carbonatite lavas.

\begin{tabular}{|c|c|c|c|c|c|c|c|c|c|c|c|c|c|c|c|c|c|c|c|c|}
\hline \multirow{2}{*}{$\begin{array}{l}\text { Sumple } \\
\text { wes. }\end{array}$} & \multicolumn{5}{|c|}{ Huilala-Ungongué } & \multicolumn{5}{|l|}{ Ipunda } & \multicolumn{5}{|l|}{ Jango } & \multicolumn{5}{|c|}{ Utihohala } \\
\hline & CAT-10a & CAT-10b & CAT-11a & CAT-11b & CAT-11C & CAT. $79 \mathrm{a}$ & CAT-79b & CAT- $79 \mathrm{~b}$ & CAT-79C & САT-79c & AC-39a & $A C-39 a$ & AC-41a & $\underline{A C-41 b}$ & AC-41b & AC-17a & $A C-17 \mathrm{a}$ & $A C-17 b$ & $A C-17 C$ & $A C-17 d$ \\
\hline $\mathrm{SiO}_{2}$ & 0.07 & 0.08 & 0.11 & 0.38 & 0.03 & 0.04 & 0.04 & 0.08 & 0 & 0.07 & 0.01 & 0.09 & 0.09 & 0.09 & 0.11 & 0.08 & 0.15 & 0.32 & 0.05 & 0.11 \\
\hline $\mathrm{TiO}_{2}$ & 14.35 & 9.25 & 15.29 & 8.51 & 12.83 & 6.49 & 11.33 & 9.99 & 8.94 & 12.11 & 5.36 & 12.23 & 7.97 & 12.87 & 7.03 & 11.87 & 5.09 & 7.86 & 13.08 & 12.02 \\
\hline $\mathrm{Al}_{2} \mathrm{O}_{3}$ & 7.24 & 5.84 & 5.86 & 13.06 & 7.77 & 5.38 & 4.53 & 5.78 & 3.05 & 3.16 & 8.98 & 3.18 & 9.65 & 6.8 & 8.1 & 4.14 & 10.82 & 14.28 & 3.87 & 8.26 \\
\hline $\mathrm{Cr}_{2} \mathrm{O}_{3}$ & 0.02 & 0.01 & 0.04 & 0.02 & 0.04 & 0.05 & 0.06 & 0.06 & 0.08 & 0.12 & 0 & 0.07 & 0.03 & 0.03 & 0 & 0.06 & 0.05 & 0.04 & 0.02 & 0.01 \\
\hline $\mathrm{Fe}_{2} \mathrm{O}_{3}$ & 37.53 & 48.42 & 34.62 & 42.84 & 40.2 & 53.6 & 45.46 & 46.81 & 50.85 & 44.04 & 52.46 & 44.19 & 47.51 & 40.69 & 50.47 & 44,45 & 50.56 & 42.47 & 43.59 & 41.56 \\
\hline $\mathrm{FeO}$ & 29.64 & 26.9 & 38.29 & 20.92 & 28.55 & 25.86 & 30.16 & 26.77 & 29.71 & 34.27 & 22.29 & 32.8 & 22.06 & 30.09 & 23.32 & 31.12 & 21.81 & 20.97 & 29.03 & 25.35 \\
\hline $\mathrm{V}_{2} \mathrm{O}_{3}$ & 0.05 & 0 & 0.17 & 0 & 0.02 & 0.05 & 0.08 & 0.03 & 0.09 & 0.14 & 0.03 & 0.17 & 0 & 0 & 0.02 & 0.08 & 0.06 & 0.02 & 0.01 & 0.04 \\
\hline $\mathrm{MnO}$ & 1.16 & 1.58 & 0.6 & 2.15 & 1.21 & 1.31 & 1.16 & 1.51 & 1.1 & 0.71 & 1.58 & 0.94 & 2.07 & 0.93 & 2.53 & 1.12 & 1.73 & 1.57 & 2.14 & 2.63 \\
\hline $\mathrm{MgO}$ & 9.59 & 7.96 & 4.85 & 12.08 & 9.46 & 6.94 & 7.14 & 8.4 & 5.76 & 5.06 & 8.74 & 5.95 & 10.36 & 8.61 & 8.59 & 6.87 & 9.12 & 11.99 & 8.2 & 10.28 \\
\hline $\mathrm{ZnO}$ & 0.11 & 0.04 & 0.03 & 0.08 & 0.11 & 0.17 & 0.16 & 0.09 & 0.1 & 0.1 & 0.17 & 0.1 & 0.13 & 0.11 & 0.15 & 0.02 & 0.13 & 0.19 & 0.19 & 0.08 \\
\hline Total & 99.76 & 100.09 & 99.86 & 100.04 & 100.22 & 99.9 & 100.12 & 99.51 & 99.67 & 99.77 & 99.63 & 99.72 & 99.87 & 100.22 & 100.32 & 99.82 & 99.52 & 99.71 & 100.18 & 100.35 \\
\hline apfu & & & & & & & & & & & & & & & & & & & & \\
\hline $\mathrm{Si}$ & 0.002 & 0.003 & 0.004 & 0.013 & 0.001 & 0.001 & 0.002 & 0.003 & 0 & 0.002 & 0 & 0.003 & 0.003 & 0.003 & 0.004 & 0.003 & 0.005 & 0.01 & 0.002 & 0.004 \\
\hline $\mathrm{Ti}$ & 0.369 & 0.242 & 0.408 & 0.209 & 0.328 & 0.172 & 0.3 & 0.262 & 0.243 & 0.329 & 0.139 & 0.33 & 0.202 & 0.333 & 0.181 & 0.316 & 0.13 & 0.193 & 0.344 & 0.305 \\
\hline Al & 0.292 & 0.24 & 0.245 & 0.503 & 0.311 & 0.224 & 0.188 & 0.238 & 0.13 & 0.134 & 0.364 & 0.134 & 0.383 & 0.275 & 0.327 & 0.173 & 0.433 & 0.549 & 0.16 & 0.328 \\
\hline $\mathrm{Cr}$ & 0.001 & 0 & 0.001 & 0.001 & 0.001 & 0.001 & 0.002 & 0.002 & 0.002 & 0.003 & 0 & 0.002 & 0.001 & 0.001 & 0 & 0.002 & 0.001 & 0.001 & 0.001 & 0 \\
\hline $\mathrm{Fe}^{3+}$ & 0.965 & 1.27 & 0.925 & 1.053 & 1.029 & 1.425 & 1.205 & 1.23 & 1.381 & 1.196 & 1.357 & 1.193 & 1.205 & 1.052 & 1.302 & 1.185 & 1.293 & 1.043 & 1.148 & 1.054 \\
\hline $\mathrm{Fe}^{2+}$ & 0.847 & 0.784 & 1.137 & 0.572 & 0.812 & 0.764 & 0.888 & 0.781 & 0.897 & 1.035 & 0.641 & 0.984 & 0.622 & 0.865 & 0.669 & 0.922 & 0.62 & 0.572 & 0.849 & 0.715 \\
\hline v & 0.001 & 0 & 0.005 & 0 & 0.001 & 0.001 & 0.002 & 0.001 & 0.002 & 0.004 & 0.001 & 0.005 & 0 & 0 & 0.001 & 0.002 & 0.002 & 0.001 & 0 & 0.001 \\
\hline $\mathrm{Mn}$ & 0.034 & 0.047 & 0.018 & 0.06 & 0.035 & 0.039 & 0.035 & 0.045 & 0.034 & 0.022 & 0.046 & 0.028 & 0.059 & 0.027 & 0.073 & 0.033 & 0.05 & 0.043 & 0.063 & 0.075 \\
\hline $\mathrm{Mg}$ & 0.488 & 0.414 & 0.257 & 0.588 & 0.48 & 0.366 & 0.375 & 0.437 & 0.31 & 0.272 & 0.448 & 0.318 & 0.521 & 0.441 & 0.439 & 0.363 & 0.462 & 0.583 & 0.428 & 0.517 \\
\hline $\mathrm{Zn}$ & 0.003 & 0.001 & 0.001 & 0.002 & 0.003 & 0.004 & 0.004 & 0.002 & 0.003 & 0.003 & 0.004 & 0.003 & 0.003 & 0.003 & 0.004 & 0.001 & 0.003 & 0.005 & 0.005 & 0.002 \\
\hline
\end{tabular}


Table 4. EPMA analyses: fluorapatite microphenocrysts composition of the Catanda lavas.

\begin{tabular}{|c|c|c|c|c|c|c|c|c|c|c|c|c|c|c|c|c|c|c|c|c|}
\hline & 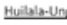 & zongué & & & & pans & & & & & $\ln n$ & & & & & Utihohala & & & & \\
\hline 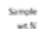 & CAT212-51 & CAT11.52 & CAT12.54 & CAT11.59 & CAT11-62 & CAT72.34 & CAT79.35 & CAT79-36 & CAT79-40 & CAID9-43 & $\mathrm{AC}(39.05$ & $\stackrel{A C 39.07}{ }$ & $A C 39.08$ & $\stackrel{A C 39-10}{A 0}$ & $A C(39-11$ & CAT25-67 & CAT25-68 & CAT25-69 & CAI25.70 & CAT25.71 \\
\hline $\mathrm{soO}_{1}$ & 0.65 & 0.74 & 0.68 & 1.36 & 0.99 & 0.35 & 133 & 0.43 & 0.45 & 0.55 & 0.6 & 183 & 1.78 & 0.5 & 0.11 & 1.26 & 0.84 & 1.44 & 2.42 & 1.26 \\
\hline Mno & 0 & 0.04 & 0.13 & 0.04 & . & 0 & 0 & 0.03 & 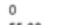 & 0.1 & 0.06 & 0.05 & & 0.01 & & & 0.02 & & 0.07 & 0.06 \\
\hline coo & 56.25 & 55.74 & 56.06 & 55.81 & 55.99 & 55.63 & 55.78 & 56.01 & 55.98 & 56.11 & 55.76 & 55.12 & 55.28 & 55.11 & 55.15 & 55.64 & 56.27 & 56.15 & 55.67 & 55.98 \\
\hline $\mathrm{Na}_{2} \mathrm{O}$ & 0.19 & 0.14 & 0.2 & 0.14 & 0.22 & 0.16 & 0.29 & 0.27 & 0.23 & 0.25 & 0.28 & 0.31 & 0.3 & 0.24 & 0.24 & 0.32 & 0.22 & 0.24 & 0.26 & 0.26 \\
\hline$P_{3} O_{s}$ & 4131 & 41.69 & 41.42 & 40.09 & 40.68 & 42.31 & 40.29 & 42.2 & 42.21 & 41.86 & 41.32 & 39.7 & 39.88 & 42.05 & 42.47 & 39.73 & 40.54 & 39.6 & 38.02 & 39.88 \\
\hline $\mathrm{La}_{3} \mathrm{O}_{\mathrm{i}}$ & 0.13 & 0.18 & 0.07 & 0 & 0.18 & 0.08 & 0.13 & 0 & 0.15 & 0.22 & 0.1 & 0.28 & 0.26 & 0.11 & 0.03 & 0.08 & 0.09 & 0.07 & 0.32 & 0.14 \\
\hline$c_{e, 0,0}$ & 0.35 & 0.28 & 0.24 & 0.35 & 0.29 & 0.27 & 0.36 & 0.25 & 0.21 & 0.14 & 0.27 & 0.62 & 0.49 & 0.39 & 0.2 & 0.28 & 0.18 & 0.29 & 0.74 & 0.26 \\
\hline seo & 0.37 & 0.33 & 0.38 & 0.34 & 0.46 & 0.43 & 0.35 & 0.45 & 0.37 & 0.35 & 0.52 & 0.46 & 0.46 & 0.51 & 0.52 & 0.41 & 0.31 & 0.33 & 0.51 & 0.43 \\
\hline ; & 1.37 & 1.61 & 15 & 1.14 & 1.32 & 1.7 & 0.98 & 1.71 & 1.15 & 1.5 & 1.57 & 106 & 1.09 & 181 & 1.95 & 0.87 & 1.34 & 1.25 & 1.05 & 1.12 \\
\hline a & 0.03 & 0.04 & 0 & 0.05 & 0.05 & 0.1 & 0.09 & 0.06 & 0.08 & 0.09 & 0.1 & 0.06 & 0.09 & 0.05 & 0.11 & 0.12 & 0.13 & 0.13 & 0.11 & 0.1 \\
\hline $\mathrm{H}_{2} \mathrm{O}$ & 1.14 & 1.03 & 1.08 & 1.22 & 1.15 & 0.97 & 1.29 & 0.98 & 1.24 & 1.07 & 1.02 & 126 & 1.24 & 0.92 & 0.84 & 1.32 & 111 & $\begin{array}{l}1.14 \\
.503\end{array}$ & 1.23 & 1.22 \\
\hline Oef & 0.58 & 0.68 & 0.63 & 0.48 & 0.56 & 0.71 & 0.41 & 0.72 & 0.49 & 0.63 & 0.66 & 0.45 & 0.46 & 0.76 & 0.82 & 0.37 & 0.56 & 0.53 & 0.44 & 0.47 \\
\hline$a-a$ & 0.01 & 0.01 & 0 & 0.01 & 0.01 & 0.02 & 0.02 & 0.01 & 0.02 & 0.02 & 0.02 & 0.01 & 0.02 & 0.01 & 0.02 & 0.03 & 0.03 & 0.03 & 0.02 & 0.02 \\
\hline Tocal & 101.2 & 101.13 & 101.14 & 100.05 & 100.77 & 101.26 & 100.46 & 101.65 & 101.57 & 101.57 & 100.92 & 100.29 & 100.39 & 100.93 & 100.89 & 99.69 & 100.45 & 100.11 & 99.94 & 100.22 \\
\hline$=$ & 0.108 & 0.123 & 0.11 & & 01 & 0.058 & 0,22 & & & & 0101 & & & & & & 0.141 & & 113 & 13 \\
\hline Mn & 0 & 0.005 & 0.019 & 0.006 & & 0 & 0 & 0.004 & 0 & 0. & 0.009 & 007 & 0.3011 & 0.001 & 0.017 & 0.009 & 0.0 & 0.24 & 0.011 & 0.009 \\
\hline$c a$ & 10.067 & 9.951 & 10.025 & 10.106 & 10.078 & 9. & 10.065 & & 9.9 & & 10.008 & & 9.993 & & & 10.138 & 10.162 & 10.198 & 10.204 & 10.154 \\
\hline Na & 0.061 & 0.047 & 0.0 & 0.045 & o. & & 0.0 & 0.087 & & & & 22 & & & & & 0.072 & & 188 & 0.086 \\
\hline${ }^{p}$ & 5.842 & 5.88 & 5.8 & 5.736 & & & & 59 & & & 5. & & & & & & 5.7 & & 06 & 5.715 \\
\hline Lo & 0.008 & 0.011 & 0.0 & $\circ$ & 0.011 & 0.005 & 0.008 & & 0.009 & & 0.006 & & 0.016 & & & & 0.005 & 05 & ne. & $\begin{array}{l}0.009 \\
\end{array}$ \\
\hline ce & 0.021 & 0.017 & 0.015 & 0.02 & 0.018 & 0.017 & 0.022 & 0.015 & $\begin{array}{l}0.013 \\
\end{array}$ & 0.0 & $\begin{array}{l}0.017 \\
0.05\end{array}$ & 0.038 & & $\begin{array}{l}0.024 \\
0.05\end{array}$ & 0.012 & $\begin{array}{l}0.017 \\
0.04\end{array}$ & 0.011 & $\begin{array}{l}0.018 \\
0.033\end{array}$ & $\begin{array}{l}0.046 \\
0.051\end{array}$ & $\begin{array}{l}0.016 \\
0.024\end{array}$ \\
\hline st & $\begin{array}{l}0.036 \\
0.725\end{array}$ & $\begin{array}{l}0.032 \\
0.848\end{array}$ & $\begin{array}{l}0.037 \\
0.0793\end{array}$ & 0.033 & 0.045 & $\begin{array}{l}0.042 \\
0.897\end{array}$ & $\begin{array}{l}0.035 \\
0.523\end{array}$ & $\begin{array}{l}0.043 \\
0.898\end{array}$ & $\begin{array}{l}0.035 \\
0.605\end{array}$ & 0.0 & $\begin{array}{l}0.05 \\
0.833\end{array}$ & $\begin{array}{l}0.046 \\
0.0656\end{array}$ & $\begin{array}{l}0.045 \\
0.58\end{array}$ & $\begin{array}{l}0.05 \\
0.956\end{array}$ & 113 & 4.9 & $\begin{array}{l}0.03 \\
0.713\end{array}$ & $\begin{array}{l}0.033 \\
0.69\end{array}$ & $\begin{array}{l}0.051 \\
0.0566\end{array}$ & $\begin{array}{l}0.042 \\
0.957\end{array}$ \\
\hline g' & $\begin{array}{l}0.725 \\
0.007\end{array}$ & $\begin{array}{l}0.848 \\
0.01\end{array}$ & $\begin{array}{l}0.793 \\
0.001\end{array}$ & $\begin{array}{l}0.61 \\
0.015\end{array}$ & $\begin{array}{l}0.7 \\
0.013\end{array}$ & $\begin{array}{l}0.8922 \\
0.027\end{array}$ & $\begin{array}{l}0.523 \\
0.025\end{array}$ & $\begin{array}{l}0.898 \\
0.016\end{array}$ & $\begin{array}{l}0.605 \\
0.023\end{array}$ & $\begin{array}{l}0.7866 \\
0.024\end{array}$ & $\begin{array}{l}0.832 \\
0.029\end{array}$ & $\begin{array}{l}0.505 \\
0.018\end{array}$ & $\begin{array}{l}0.5811 \\
0.025\end{array}$ & $\begin{array}{l}0.956 \\
0.015\end{array}$ & 1.0 & $\begin{array}{l}0.469 \\
0.034\end{array}$ & $\begin{array}{l}0.713 \\
0.036\end{array}$ & $\begin{array}{l}0.669 \\
0.098\end{array}$ & $\begin{array}{l}0.566 \\
0.0311\end{array}$ & $\begin{array}{l}0.5977 \\
0.928\end{array}$ \\
\hline OH & $\begin{array}{l}0.007 \\
1.267\end{array}$ & $\begin{array}{l}0.01 \\
1.141\end{array}$ & $\begin{array}{l}.0 .001 \\
1.206\end{array}$ & $\begin{array}{l}0.0115 \\
1.375\end{array}$ & & $\begin{array}{l}0.027 \\
1.08\end{array}$ & $\begin{array}{l}0.025 \\
1.452\end{array}$ & $\begin{array}{l}0.0116 \\
1085\end{array}$ & $\begin{array}{l}0.023 \\
1.371\end{array}$ & $\begin{array}{l}0.024 \\
1.19\end{array}$ & $\begin{array}{l}0.029 \\
1.139\end{array}$ & $\begin{array}{l}0.018 \\
1.416\end{array}$ & $\begin{array}{l}0.025 \\
1.395\end{array}$ & $\begin{array}{l}0.015 \\
1.029\end{array}$ & $\begin{array}{l}0.031 \\
0.939\end{array}$ & $\begin{array}{l}0.034 \\
1.998\end{array}$ & $\begin{array}{l}0.036 \\
1.251\end{array}$ & $\begin{array}{l}0.0018 \\
1.293\end{array}$ & $\begin{array}{l}0.031 \\
1.403\end{array}$ & $\begin{array}{l}0.028 \\
1.375\end{array}$ \\
\hline $\mathrm{OH}$ & & 1.1441 & 1.206 & 1.375 & 1.286 & 1.08 & 1.452 & 1.085 & 1.371 & 1.19 & 1.139 & 1416 & 1.395 & 1029 & & & 1251 & & 1.403 & 1.375 \\
\hline
\end{tabular}


Table 5. EPMA analyses: phlogopite microphenocrysts composition in different

Catanda lavas localities.

\begin{tabular}{|c|c|c|c|c|c|c|c|c|c|c|c|c|c|c|c|}
\hline \multicolumn{8}{|c|}{ Huilala-Ungongué } & \multicolumn{3}{|l|}{ Ipunda } & \multicolumn{3}{|l|}{ Jango } & \multicolumn{2}{|c|}{ Utihohala } \\
\hline $\begin{array}{c}\text { Sumper } \\
\text { mes }\end{array}$ & $\underline{\text { CAT-10 }}$ & $\underline{\text { CAT-10 }}$ & $\underline{\text { CAT-10 }}$ & CAT-11 & $\underline{\text { CAT-11 }}$ & CAT-11 & CAT-11 & CAT-79 & CAT-79 & $\underline{\text { CAT-79 }}$ & $\underline{A C-38}$ & $\underline{A C-38}$ & $\underline{A C-39}$ & AC-17 & $\underline{A C-17}$ \\
\hline $\mathrm{SiO}_{2}$ & 35.93 & 35.07 & 36.48 & 35.98 & 35.88 & 35.14 & 35.90 & 38.79 & 36.79 & 36.22 & 36.45 & 36.67 & 38.51 & 38.53 & 36.29 \\
\hline $\mathrm{TiO}_{2}$ & 4.2 & 1.19 & 4.05 & 1.46 & 1.95 & 1.38 & 1.61 & 2.25 & 1.17 & 1.75 & 1.33 & 1.62 & 1.57 & 1.28 & 1.50 \\
\hline $\mathrm{Al}_{2} \mathrm{O}_{3}$ & 16.91 & 15.46 & 16.91 & 15.31 & 16.65 & 15.31 & 15.36 & 14.25 & 15.9 & 15.88 & 15.56 & 16.01 & 15.22 & 14.29 & 15.66 \\
\hline $\mathrm{FeO}$ & 10.54 & 10.32 & 10.33 & 20.20 & 19.16 & 19.76 & 19.66 & 9.53 & 18.1 & 20.99 & 19.06 & 19.21 & 19.73 & 19.51 & 18.60 \\
\hline $\mathrm{MnO}$ & 0.09 & 0.32 & 0.09 & 0.49 & 0.44 & 0.35 & 0.34 & 0.16 & 0.45 & 0.34 & 0.46 & 0.41 & 0.37 & 0.40 & 0.39 \\
\hline $\mathrm{MgO}$ & 17.43 & 19.59 & 17.62 & 11.07 & 10.88 & 10.50 & 10.90 & 18.88 & 11.72 & 9.66 & 11.82 & 11.40 & 10.53 & 10.35 & 10.84 \\
\hline $\mathrm{CaO}$ & 0.01 & 0.22 & 0.09 & 0.03 & 0.02 & 0.06 & 0.02 & 0.83 & 0.08 & 0.08 & 0.04 & 0.03 & 0.06 & 0.05 & 0.06 \\
\hline $\mathrm{Na}_{2} \mathrm{O}$ & 0.58 & 0.07 & 0.47 & 0.22 & 0.29 & 0.36 & 0.25 & 0.37 & 0.14 & 0.33 & 0.21 & 0.15 & 0.26 & 0.25 & 0.38 \\
\hline $\mathrm{K}_{2} \mathrm{O}$ & 0.62 & 10.24 & 9.56 & 9.87 & 10.01 & 8.74 & 9.98 & 5.90 & 9.97 & 9.95 & 9.88 & 9.96 & 9.43 & 9.38 & 9.88 \\
\hline SrO & 0.01 & 0 & 0 & 0 & 0 & 0 & 0 & 0 & 0 & 0 & 0 & 0 & 0 & 0 & 0 \\
\hline $\mathrm{BaO}$ & 0.39 & 0.39 & 0.38 & 0.16 & 0.19 & 0.04 & 0.12 & 0.21 & 0.08 & 0.22 & 0.06 & 0.15 & 0.04 & 0.05 & 0.15 \\
\hline $\mathrm{ZnO}$ & 0.02 & 0.09 & 0.02 & 0.09 & 0.13 & 0.10 & 0.07 & 0.04 & 0.09 & 0.06 & 0.02 & 0.17 & 0 & 0.09 & 0 \\
\hline $\mathrm{F}$ & 0.2 & 0.34 & 0.22 & 0.32 & 0.31 & 0.33 & 0.26 & 0.23 & 0.33 & 0.16 & 0.47 & 0.47 & 0.30 & 0.27 & 0.35 \\
\hline $\mathrm{Cr}_{2} \mathrm{O}_{3}$ & 0.05 & 0.07 & 0.07 & 0.11 & 0.05 & 0.08 & 0.09 & 0.16 & 0.21 & 0.21 & 0.03 & 0.15 & 0.14 & 0.12 & 0.05 \\
\hline $\mathrm{NiO}$ & 0 & 0.01 & 0.03 & 0.01 & 0 & 0.04 & 0 & 0.05 & 0 & 0 & 0.05 & 0.01 & 0.02 & 0.01 & 0 \\
\hline $\mathrm{Li}_{2} \mathrm{O}$ & 0.76 & 0.51 & 0.92 & 0.78 & 0.75 & 0.53 & 0.75 & 1.58 & 1.01 & 0.84 & 0.91 & 0.97 & 1.50 & 1.51 & 0.86 \\
\hline $\mathrm{H}_{2} \mathrm{O}^{*}$ & 4.03 & 3.81 & 4.06 & 3.76 & 3.81 & 3.65 & 3.77 & 4 & 3.81 & 3.86 & 3.73 & 3.77 & 3.90 & 3.87 & 3.74 \\
\hline ubtotal & 100.75 & 97.68 & 101.3 & 99.86 & 100.51 & 97.37 & 99.09 & 97.24 & 99.84 & 100.53 & 100.07 & 101.14 & 101.59 & 99.94 & 98.74 \\
\hline $\mathrm{O} / \mathrm{F}$ & 0.08 & 0.14 & 0.09 & 0.13 & 0.13 & 0.14 & 0.11 & 0.10 & 0.14 & 0.07 & 0.20 & 0.20 & 0.13 & 0.11 & 0.15 \\
\hline Total & 100.67 & 97.54 & 101.21 & 99.73 & 100.38 & 97.23 & 98.98 & 97.14 & 99.70 & 100.46 & 99.87 & 100.94 & 101.46 & 99.83 & 98.59 \\
\hline $\mathrm{Si}$ & 5.22 & 5.30 & 5.26 & 5.52 & 5.44 & 5.53 & 5.53 & 5.65 & 5.56 & 5.53 & 5.54 & 5.51 & 5.71 & 5.81 & 5.58 \\
\hline Al iv & 2.78 & 2.70 & 2.74 & 2.48 & 2.56 & 2.47 & 2.47 & 2.35 & 2.44 & 2.47 & 2.46 & 2.49 & 2.29 & 2.19 & 2.42 \\
\hline Al vi & 0.12 & 0.06 & 0.13 & 0.29 & 0.41 & 0.37 & 0.33 & 0.10 & 0.42 & 0.38 & 0.32 & 0.35 & 0.37 & 0.35 & 0.41 \\
\hline $\mathrm{Ti}$ & 0.46 & 0.13 & 0.44 & 0.17 & 0.22 & 0.16 & 0.19 & 0.25 & 0.13 & 0.20 & 0.15 & 0.18 & 0.17 & 0.15 & 0.17 \\
\hline $\mathrm{Cr}$ & 0.01 & 0.01 & 0.01 & 0.01 & 0.01 & 0.01 & 0.01 & 0.02 & 0.03 & 0.02 & 0 & 0.02 & 0.02 & 0.01 & 0.01 \\
\hline $\mathrm{Fe}$ & 1.28 & 1.30 & 1.25 & 2.59 & 2.43 & 2.60 & 2.54 & 1.16 & 2.28 & 2.68 & 2.42 & 2.42 & 2.45 & 2.46 & 2.39 \\
\hline $\mathrm{Mn}$ & 0.01 & 0.04 & 0.01 & 0.06 & 0.06 & 0.05 & 0.04 & 0.02 & 0.06 & 0.04 & 0.06 & 0.05 & 0.05 & 0.05 & 0.05 \\
\hline $\mathrm{Mg}$ & 3.77 & 4.41 & 3.78 & 2.53 & 2.46 & 2.46 & 2.51 & 4.10 & 2.64 & 2.20 & 2.68 & 2.55 & 2.33 & 2.33 & 2.48 \\
\hline $\mathrm{Zn}$ & 0 & 0.01 & 0 & 0.01 & 0.01 & 0.01 & 0.01 & 0 & 0.01 & 0.01 & 0 & 0.02 & 0 & 0.01 & 0 \\
\hline $\mathrm{Ni}$ & 0 & 0 & 0 & 0 & 0 & 0 & 0 & 0.01 & 0 & 0 & 0.01 & 0 & 0 & 0 & 0 \\
\hline $\mathrm{Li}^{*}$ & 0.44 & 0.31 & 0.53 & 0.48 & 0.45 & 0.34 & 0.47 & 0.93 & 0.61 & 0.52 & 0.55 & 0.59 & 0.90 & 0.91 & 0.53 \\
\hline $\mathrm{Ca}$ & 0 & 0.04 & 0.01 & 0.01 & 0,0 & 0.01 & 0 & 0.13 & 0.01 & 0.01 & 0.01 & 0 & 0.01 & 0.01 & 0.01 \\
\hline $\mathrm{Na}$ & 0.16 & 0.02 & 0.13 & 0.07 & 0.09 & 0.11 & 0.08 & 0.11 & 0.04 & 0.1 & 0.06 & 0.04 & 0.08 & 0.07 & 0.11 \\
\hline K & 1.78 & 1.98 & 1.76 & 1.93 & 1.94 & 1.96 & 1.96 & 1.10 & 1.92 & 1.94 & 1.91 & 1.91 & 1.78 & 1.80 & 1.84 \\
\hline $\mathrm{Sr}$ & 0 & 0 & 0 & 0 & 0 & 0 & 0 & 0 & 0 & 0 & 0 & 0 & 0 & 0 & 0 \\
\hline $\mathrm{Ba}$ & 0.02 & 0.02 & 0.02 & 0.01 & 0.01 & 0 & 0.01 & 0.01 & 0 & 0.01 & 0 & 0.01 & 0 & 0 & 0.01 \\
\hline $\mathrm{OH}^{*}$ & 3.91 & 3.84 & 3.90 & 3.85 & 3.85 & 3.83 & 3.87 & 3.89 & 3.84 & 3.92 & 3.78 & 3.78 & 3.86 & 3.87 & 3.83 \\
\hline $\mathrm{F}$ & 0.09 & 0.16 & 0.10 & 0.15 & 0.15 & 0.17 & 0.13 & 0.11 & 0.16 & 0.08 & 0.22 & 0.22 & 0.14 & 0.13 & 0.17 \\
\hline TOTAL & 20.06 & 20.34 & 20.08 & 20.16 & 20.09 & 20.08 & 20.13 & 19.93 & 20.15 & 20.11 & 20.18 & 20.15 & 20.15 & 20.16 & 20.12 \\
\hline $\mathrm{Y}$ total & 6.09 & 6.28 & 6.15 & 6.15 & 6.05 & 6.01 & 6.08 & 6.59 & 6.17 & 6.05 & 6.20 & 6.18 & 6.28 & 6.27 & 6.05 \\
\hline $\mathrm{X}$ total & 1.97 & 2.05 & 1.92 & 2.01 & 2.03 & 2.08 & 2.05 & 1.34 & 1.98 & 2.06 & 1.99 & 1.97 & 1.87 & 1.89 & 2.07 \\
\hline Al total & 2.90 & 2.75 & 2.87 & 2.77 & 2.97 & 2.84 & 2.79 & 2.45 & 2.85 & 2.86 & 2.79 & 2.84 & 2.66 & 2.54 & 2.84 \\
\hline$/ \mathrm{Fe}+\mathrm{Mg}$ & 0.25 & 0.23 & 0.25 & 0.51 & 0.50 & 0.51 & 0.49 & 0.22 & 0.46 & 0.55 & 0.48 & 0.49 & 0.51 & 0.51 & 0.49 \\
\hline
\end{tabular}


Table 6. Representative bulk rock chemical analyses of the Catanda carbonatite lavas.

\begin{tabular}{|c|c|c|c|c|c|c|c|c|c|c|c|}
\hline & & gue & & & & & & Ipunda & Jango & & Utihohala \\
\hline Sample & $\underline{A C-19}$ & $\underline{A C-20}$ & $\underline{A C-21}$ & $\underline{A C-24}$ & $\underline{A C-25}$ & $\underline{\mathrm{AC}-35}$ & $\underline{\mathrm{AC}-36}$ & CAT-79 & $\underline{A C-39}$ & $\underline{A C-41}$ & $\underline{\mathrm{AC}-17}$ \\
\hline wt.\% & & & & & & & & & & & \\
\hline $\mathrm{SiO}_{2}$ & 14.64 & 14.29 & 14.39 & 14.58 & 23.33 & 14.81 & 19.6 & 6.25 & 12.78 & 11.99 & 9.76 \\
\hline $\mathrm{TiO}_{2}$ & 1.45 & 1.41 & 1.45 & 1.49 & 2.35 & 1.51 & 2.21 & 0.38 & 0.68 & 0.76 & 0.24 \\
\hline $\mathrm{Al}_{2} \mathrm{O}_{3}$ & 3.11 & 3.22 & 3.16 & 3.24 & 5.92 & 3.3 & 4.75 & 1.73 & 2.43 & 2.58 & 2.33 \\
\hline $\mathrm{FeO}_{\mathrm{t}}$ & 8.94 & 8.61 & 8.71 & 9.24 & 11.28 & 9.04 & 10.58 & 4.15 & 8.12 & 8.09 & 6.32 \\
\hline $\mathrm{MnO}$ & 0.55 & 0.53 & 0.52 & 0.58 & 0.44 & 0.56 & 0.48 & 0.32 & 0.31 & 0.28 & 0.63 \\
\hline $\mathrm{MgO}$ & 8.59 & 8.61 & 8.17 & 9.09 & 9.4 & 8.97 & 9.16 & 1.36 & 9.73 & 9.45 & 9.18 \\
\hline $\mathrm{CaO}$ & 38.08 & 37.26 & 34.57 & 37.27 & 29.36 & 33.78 & 31.34 & 46.53 & 36.53 & 37.32 & 36.52 \\
\hline $\mathrm{Na}_{2} \mathrm{O}$ & 0.24 & 0.22 & 0.27 & 0.17 & 0.29 & 0.23 & 0.2 & 0.25 & 0.04 & 0.08 & 0.07 \\
\hline $\mathrm{K}_{2} \mathrm{O}$ & 0.13 & 0.15 & 0.1 & 0.14 & 0.57 & 0.14 & 0.14 & 0.22 & 0.03 & 0.02 & 0.11 \\
\hline $\mathrm{P}_{2} \mathrm{O}_{5}$ & 4.23 & 4.12 & 4.08 & 4.28 & 3.06 & 4.38 & 3.58 & 2.28 & 2.79 & 2.73 & 4.71 \\
\hline LOI & 18.5 & 20.2 & 23.1 & 18.4 & 12.9 & 21.9 & 16.8 & 35.8 & 25.7 & 25.7 & 28.6 \\
\hline TOT/C & 3.52 & 3.6 & 4.71 & 3.65 & 1.71 & 4.35 & 2.19 & 9.39 & 5.76 & 6.01 & 6.39 \\
\hline TOT/S & 0.34 & 0.31 & 0.1 & 0.2 & 0.09 & 0.11 & 0.15 & 0.02 & 0.03 & 0.06 & $<0.02$ \\
\hline Sum & 99.53 & 99.57 & 99.54 & 99.5 & 99.54 & 99.5 & 99.54 & 99.83 & 99.68 & 99.7 & 99.57 \\
\hline ppm & & & & & & & & & & & \\
\hline $\mathrm{F}$ & 5910 & 5770 & 6790 & 4470 & 5200 & 6500 & 5460 & 1570 & 4040 & 4330 & 6850 \\
\hline $\mathrm{Sc}$ & 7.4 & 8.2 & 8.8 & 9 & 17 & 9.6 & 13.6 & 7 & 36.2 & 32.9 & 14.1 \\
\hline V & 239 & 215 & 220 & 225 & 262 & 234 & 257 & 76 & 208 & 191 & 126 \\
\hline Co & 25.3 & 23.4 & 38.3 & 26.1 & 31.8 & 20.6 & 28.3 & 10.5 & 22.4 & 22.9 & 9.9 \\
\hline $\mathrm{Cu}$ & 29.67 & 32.03 & 33.88 & 34.55 & 58.65 & 30.58 & 53.45 & 8.41 & 47.49 & 58.67 & 4.74 \\
\hline $\mathrm{Ni}$ & 7 & 7 & 7.7 & 9.4 & 17.4 & 7.6 & 11.6 & 20 & 1.9 & 3,0 & 1 \\
\hline $\mathrm{Zn}$ & 120.1 & 118.3 & 125.2 & 131.8 & 110.5 & 118.1 & 114.7 & 76.1 & 64.5 & 66.5 & 122 \\
\hline $\mathrm{Rb}$ & 13.4 & 13.1 & 9.8 & 16.9 & 31.3 & 4.9 & 8.8 & 7.6 & 0.8 & 0.8 & 5.5 \\
\hline Cs & 0.8 & 0.8 & 0.6 & 1 & 0.5 & 0.2 & 0.5 & 0.1 & 0.4 & 0.2 & 0.2 \\
\hline $\mathrm{Sr}$ & 5446 & 5186 & 5147 & 5401 & 2427 & 3849 & 3249 & 2826 & 2743 & 2903 & 5491 \\
\hline $\mathrm{Ba}$ & 1413 & 1367 & 2010 & 1430 & 1357 & 1433 & 1147 & 888 & 936 & 1552 & 2416 \\
\hline La & 756.4 & 779.1 & 743 & 811 & 674.6 & 797.7 & 762.2 & 405.4 & 260 & 252.5 & 718.5 \\
\hline $\mathrm{Ce}$ & 1297.2 & 1319.5 & 1288.8 & 1388.5 & 1109.5 & 1390.1 & 1255.8 & 693.83 & 491.9 & 507.7 & 1211.6 \\
\hline $\mathrm{Pr}$ & 133.49 & 133.3 & 127.99 & 141.67 & 108.71 & 138.01 & 124.47 & 76.8 & 57.39 & 58.34 & 122.7 \\
\hline $\mathrm{Nd}$ & 451.5 & 447.2 & 434.3 & 475.1 & 358.4 & 472.2 & 416.3 & 254.6 & 217.7 & 220.1 & 406.4 \\
\hline $\mathrm{Sm}$ & 55.67 & 56.34 & 53.89 & 58.91 & 42.86 & 57.24 & 49.87 & 33.5 & 30.26 & 30.38 & 52.81 \\
\hline Eu & 14.56 & 14.74 & 13.84 & 15.3 & 11.15 & 15.04 & 13 & 9.1 & 7.68 & 8.03 & 13.7 \\
\hline Gd & 41.75 & 41.35 & 38.9 & 43.97 & 31.68 & 41.99 & 37.31 & 19.2 & 19.44 & 19.84 & 39.23 \\
\hline $\mathrm{Tb}$ & 4.09 & 4.17 & 3.96 & 4.3 & 3.11 & 4.13 & 3.62 & 2.7 & 1.86 & 2 & 3.78 \\
\hline Dy & 18.92 & 19.33 & 18.71 & 19.69 & 14.83 & 18.93 & 17.14 & 11.5 & 8.35 & 8.55 & 18.79 \\
\hline Ho & 2.74 & 2.75 & 2.82 & 2.97 & 2.14 & 2.85 & 2.58 & 1.9 & 1.28 & 1.2 & 2.5 \\
\hline $\mathrm{Er}$ & 6.62 & 7.08 & 6.35 & 6.88 & 4.99 & 6.75 & 5.38 & 4.2 & 2.56 & 2.71 & 6.2 \\
\hline Tm & 0.85 & 0.86 & 0.79 & 0.88 & 0.66 & 0.9 & 0.74 & 0.7 & 0.34 & 0.37 & 0.82 \\
\hline $\mathrm{Yb}$ & 5.44 & 5.31 & 4.29 & 5.86 & 3.94 & 5.18 & 4.1 & 3.9 & 2.07 & 2.07 & 4.89 \\
\hline Lu & 0.78 & 0.74 & 0.62 & 0.75 & 0.55 & 0.75 & 0.62 & 0.6 & 0.3 & 0.3 & 0.63 \\
\hline Y & 76.6 & 76.9 & 72.8 & 85.4 & 59.9 & 78.2 & 70.5 & 49 & 33.9 & 34 & 71.7 \\
\hline $\mathrm{Pb}$ & 7.09 & 6.89 & 7 & 5.46 & 6.17 & 7.33 & 5.82 & 15.09 & 10.54 & 7.38 & 12.76 \\
\hline $\mathrm{Nb}$ & 590 & 577 & 588 & 607 & 441 & 624 & 504 & 281 & 411 & 365 & 706 \\
\hline $\mathrm{Zr}$ & 725 & 717 & 709 & 700 & 599 & 731 & 626 & 401 & 592 & 555 & 463 \\
\hline $\mathrm{Hf}$ & 7.3 & 8.7 & 7.8 & 8.7 & 8.2 & 7.8 & 8.4 & 5.7 & 9.4 & 8.9 & 5.7 \\
\hline Ta & 20.6 & 21.3 & 22.7 & 21.1 & 16.1 & 23 & 20.2 & 12.8 & 17.8 & 16.9 & 18.2 \\
\hline Th & 40.1 & 40.7 & 40.1 & 40.2 & 29.7 & 41.6 & 35.3 & 37.4 & 27.6 & 27.4 & 45.7 \\
\hline U & 13.8 & 14.6 & 13.1 & 14.6 & 10.1 & 14.3 & 11.7 & 5.5 & 7.8 & 7.9 & 15.9 \\
\hline $\mathrm{Ga}$ & 7.3 & 6 & 6.9 & 7.7 & 10.6 & 6.3 & 10 & 2.91 & 5.2 & 5.1 & 4 \\
\hline$\Sigma$ REE & 2790 & 2831.8 & 2738.3 & 2975.8 & 2367.1 & 2951.8 & 2693.1 & 1517.9 & 1101.1 & 1114.1 & 2602.6 \\
\hline$\Sigma$ HFSE & 1342.9 & 1324 & 1327.5 & 1336.8 & 1064.3 & 1385.8 & 1158.6 & 700.52 & 1030.2 & 945.8 & 1192.9 \\
\hline
\end{tabular}


Table 7. Stable isotopic data of $\delta^{13} \mathrm{C}$ and $\delta^{18} \mathrm{O}$ of Catanda carbonatite lavas.

\begin{tabular}{|c|c|c|c|c|c|c|c|c|c|c|c|c|c|c|c|}
\hline \multirow[b]{3}{*}{ Somple } & \multicolumn{12}{|c|}{ Primary carbonate } & \multicolumn{2}{|c|}{ Secondary carbonate } & \multirow{3}{*}{\begin{tabular}{l}
\multicolumn{1}{c}{ Travertine } \\
Pedra de Água \\
$\underline{\text { AC-01t }}$
\end{tabular}} \\
\hline & \multicolumn{7}{|c|}{ Huilala - Ungongué } & \multirow{2}{*}{$\begin{array}{l}\text { Ipunda } \\
\underline{\text { CAT-79 }}\end{array}$} & \multicolumn{3}{|l|}{ Jango } & \multirow{2}{*}{$\begin{array}{l}\text { Utihohala } \\
\underline{\text { AC-17 }}\end{array}$} & \multirow{2}{*}{$\begin{array}{l}\text { Jango } \\
\text { AC-42s }\end{array}$} & \multirow{2}{*}{$\begin{array}{l}\text { Ipunda } \\
\text { CAT-79s }\end{array}$} & \\
\hline & AC-19 & $A C-20$ & $\underline{A C-21}$ & $\underline{A C-24}$ & $\underline{A C-25}$ & $A C-35$ & $A C-36$ & & $A C=39$ & AC-41 & AC-42 & & & & \\
\hline$\delta^{13} \mathrm{C}(\mathrm{V}-\mathrm{PDB})$ & -10.97 & -8.93 & -8.38 & -10.18 & -8.11 & -8.31 & -12.15 & -5.49 & -5.34 & -5.53 & -5.2 & -5.61 & -1.02 & -4.15 & 6.37 \\
\hline o (V-SMOW) & 11.66 & 10.66 & 13.44 & 11.58 & 17.85 & 11.02 & 15.79 & 14.33 & 9.33 & 10.35 & 10.29 & 14.5 & 26.95 & 27.2 & 26.42 \\
\hline
\end{tabular}

Table 8. List of the mineral phases identified in the melt inclusion assemblage hosted by magnetite phenocrysts of the Catanda lavas.

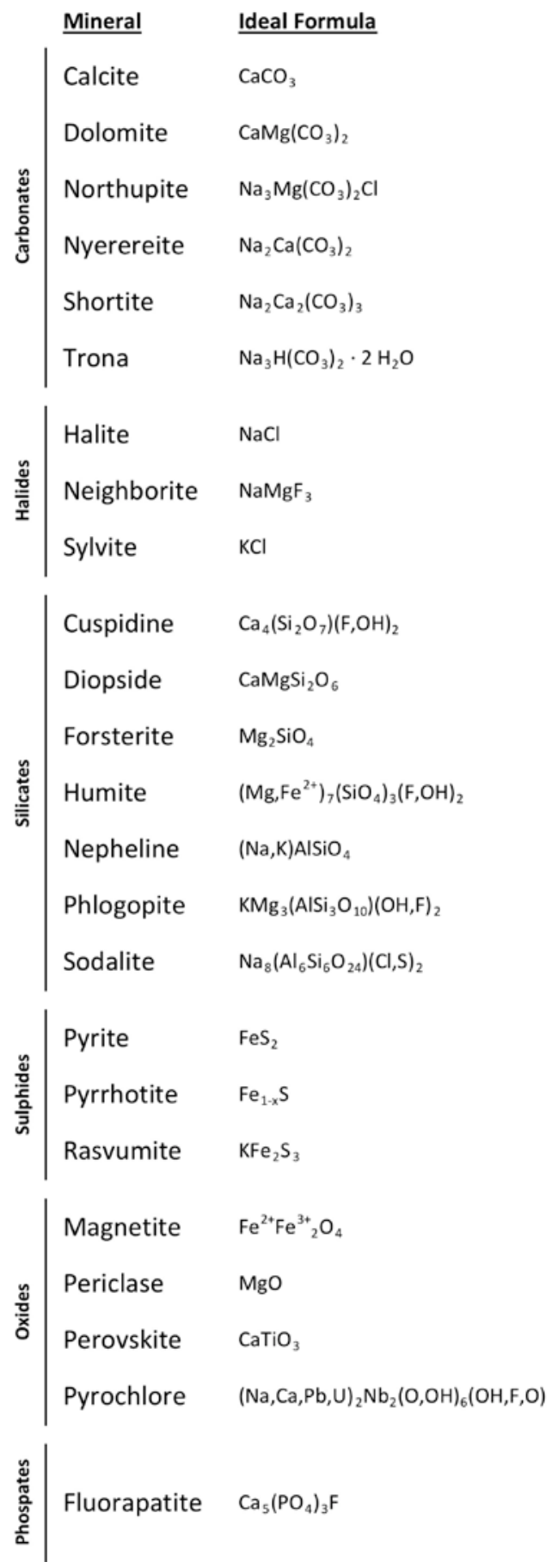

